\title{
Bitter flavour in dairy products. II. A review of bitter peptides from caseins: their formation, isolation and identification, structure masking and inhibition
}

\author{
L Lemieux, RE Simard \\ Université Laval, Centre de Recherche STELA, Ste-Foy, Quebec, Canada G1K 7P4
}

(Received 20 August 1991; accepted 26 March 1992)

\begin{abstract}
Summary - Bitterness, a flavour defect liable to be present in dairy products, is due to the accumulation of bitter-tasting peptides. These peptides are rich in hydrophobic amino acids and are formed by the action of proteolytic enzymes on casein. Many studies report the isolation, identification, and characterisation of bitter peptides from cheese and casein hydrolysates, and even their synthesis. This has been done in order to determine the structure of peptides, and also to elucidate the roles of different proteolytic enzyme systems in the development of bitterness, the exact nature of which is still hypothetical. Although bitterness has to be accepted as a necessary consequence of proteolysis, it can be mitigated by masking, removal, or prevention.
\end{abstract}

bitterness / cheese / casein hydrolysate / peptide / hydrophobicity

Résumé - L'amertume dans les produits laitiers. II. Une revue de la littérature sur la nature des peptides amers issus de la protéolyse des caséines et concernant leur formation, isolement, identification, structure, camouflage et inhibition. Bien que le défaut d'amertume dans les produits laitiers soit attribuable à la présence, en excès, de certains peptides issus de la protéolyse des caséines et riches en acides aminés hydrophobes, son mécanisme de formation n'a pas encore été complètement élucidé. Dans ce but, plusieurs peptides ont été isolés à partir de fromages ou d'hydrolysats de caséine, identifiés et même synthétisés. II a alors été possible d'établir certaines relations entre la structure de ces peptides et leur degré d'amertume. Comme le défaut d'amertume est la résultante de la protéolyse et qu'il est susceptible d'être présent dans le produit fini, des techniques telles que le camouflage, la suppression ou l'inhibition de la formation d'une trop grande quantité de peptides amers permetten d'en amoindrir les effets.

amertume / fromage / hydrolysat de caséine / peptide / hydrophobicité 


\section{INTRODUCTION}

In a previous paper we have described the possible causes of bitter flavour defect in dairy products, mainly cheese (Lemieux and Simard, 1991). It has also been mentioned that, in cheese varieties other than Cottage, bitter flavour development is associated with proteolysis (Stone and Naff, 1967), which is a basic step in the pathway of flavour development, relying on microbial metabolism of lactic acid bacteria, proteases (chymosin, plasmin, bacterial and mould enzymes) and peptidases (Minamiura et al, 1972a; Clegg et al, 1974a; Creamer, 1979; Bartels et al, 1987b).

$\alpha_{s 1^{-}}, \alpha_{s 2^{-}}, \beta-$ and $\kappa$-caseins are the main proteins found in cheese. Peptides and amino acids result from their hydrolysis during the cheese manufacturing and ripening processes. These peptides, once isolated and identified, can be evaluated as bitter or not from the hydrophobic property of their amino acid side-chain according to the $Q$-rule proposed by Ney (1971). Detection of bitterness in cheese is possible when the concentration of bitter peptides exceeds a certain threshold level. Indeed, cheese is dynamic in its flavour development, and its bitterness does not result from real off-tasting substances, but from an imbalance which pushes a normal constituent, bitter peptides, to too high a level (Ney, 1971, 1979, 1981).

Although progress has been made to minimise the risk of bitterness in cheese, the exact roles of different proteolytic enzyme systems in the development of bitterness are still hypothetical and the subject of some controversial theories. Among these, one presented by Czulak (1959) proposed that non-bitter starters were capable of degrading bitter peptides released by rennet action to non-bitter products, while Jago (1962) concluded that the differences between bitter and non-bitter strains were due to the inability of bitter strains to hydrolyse the bitter peptides produced by rennet. An experiment conducted by Emmons et al (1962a) led them to suggest that strains which produce bitter cheese are deficient in proteolytic enzymes that normally decompose the bittertasting peptides. Later on, the hypothesis of Lowrie and Lawrence (1972) postulated that all starter streptococci have the potential to produce bitter cheese. Noomen (1983) has recently reported that interactions between the 3 proteolytic systems of rennet enzymes (predominantly chymosin), starter enzymes, and milk proteinases (plasmin) have an important influence on the content of bitter peptides in cheese without a surface flora, such as Goudatype and Noordhollandse Meshanger.

Different methods have been developed for the isolation of bitter peptides from various types of cheese. Following their identification, some of these bitter peptides have been shown to be derived from the middle portion of $\beta$-casein, and some others from the C-terminal portions of $\alpha_{s 1^{-}}$and $\beta$ caseins. However, it could not be established, in any case, that one or more of the peptides isolated formed the main source of the bitter flavour defect in cheese (Visser, 1981).

Synthesis of bitter peptides, analogues and peptides with simplified structure has given rise to studies on structure-taste relationship, providing more information about the mechanism of bitterness. The relative peptide bitterness has been organoleptically determined via a panel evaluation of a series of caffeine or quinine sulphate solutions of decreasing concentration.

Although enzymic hydrolysis has the advantage of retaining the nutritional value of the protein, it is often associated with the occurrence of bitter peptides which make the product unpalatable. The role of the 
endopeptidases is to split the protein molecule primarily into peptides, while that of exopeptidases is to remove 1 or 2 amino acids from the ends of the peptide molecules. Digestion of casein with the endopeptidase trypsin has thus been shown to result in the formation of one or more bitter peptides for which various amino acid compositions and molecular sizes have been reported (Gordon and Speck, 1965b; Matoba et al, 1970; Sullivan and Jago, 1972). Research is also being carried out to find ways to mask or eliminate bitterness off-flavour from these products of hydrolysis. However, before their application, these measures will have to be recognised as safe for the consumer.

This review article on bitter peptides examines their: 1), hydrophobic amino acid side chain; 2), mechanism of formation; 3 ), isolation and identification; 4), structure; 5), masking and inhibition.

\section{GENERALITIES ABOUT THE PERCEPTION OF BITTER TASTE}

Sweet, sour, salty and bitter: the 4 basic taste qualities can be recognised by the human tongue. They are respectively represented by sucrose, hydrochloric acid, sodium chloride and quinine. A fifth taste, attributed to monosodium - $\mathrm{L}$ - glutamate and nucleotides, is called "umami", which means deliciousness in Japanese because it has a flavour-enhancing effect (lkeda, 1909). The back of the tongue is most sensitive to the bitter taste. For a substance to exhibit bitterness, it must be at least slightly soluble in water. The perception or threshold limit is then defined as the lowest concentration of the compound which can be differentiated from water alone. The optimal temperature for the perception of bitterness is $10^{\circ} \mathrm{C}$. Among the basic tastes, bitterness is the only one that could be de- tected with more sensitivity than umami (Yamaguchi, 1991). The bitter taste response is low but the lingering sensation after a bitter stimulation suggests that the binding of bitter molecules to the bitter receptor is of greater duration than the binding to sugars of the sweet receptor.

\section{Sources of bitterness}

It is now accepted that the bitter flavour produced during the enzymic hydrolysis of casein is due to some types of peptide (Fujimaki et al, 1970a). The first scientist to report that cheese bitterness resulted from a peptide was Raadsvell (1953), who also initiated the isolation of bitter peptides from casein hydrolysates (Carr et al, 1956; Gordon and Speck, 1965b) and from cheese (Harwalkar and Elliott, 1965). As reported by Ney (1979) many other substances, such as amino acids, amines, amides, substituted amides, long chain ketones and some monoglycerides present in cheese might also add to its bitterness. Among proteins, casein produce more bitterness than others and among the different caseins, $\alpha_{s 1}$-casein is regarded as the main source of bitter peptides (Richardson and Creamer, 1973; Adda et al, 1982).

\section{History of bitter taste evaluation}

In the early sixties, Tanford (1962) calculated the free energies of transfer (in calories) of the amino acid side chains from ethanol to water. Dunhill (1965) then introduced the expression "hydrophobicity" for these values (Guigoz and Solms, 1976). The way for a calculation of bitterness was later opened by Ney (1971) who, introducing Tanford values, published the $Q$ hypothesis, which establishes a semiquantitative relationship between the amino acid composition of a peptide and its 
bitterness. Another hydrophobicity scale for the amino acids has been proposed by Bull and Breese (1974). It is based on the effect of the amino acids on the surface tension of water (the greater the surface tension lowering, the greater the hydrophobicity). Leucine was found to be the most surface active of the amino acids.

According to Ney (1979), no particular amino acid or sequence was needed to impart the bitter taste. However, Japanese workers (eg, Kanehisa et al, 1984; Shinoda et al, 1985a, b; 1986a, b) later proved, by synthesising bitter peptides and several analogues, that the nature of the terminal amino acids and their steric parameters had some influence on the intensity of bitter taste.

Independent of Ney (1971), Matoba and Hata (1972) also proposed that hydrophobic amino acid side chains are responsible for the bitter taste, regardless of the amino acid sequence. Furthermore, they observed that a hydrophobic amino acid exerted the strongest bitterness when both its end were blocked, eg by forming peptide linkages. Bitterness was weaker when the amino acid was in a terminal position, and weakest when it was free.

Ney's (1971) hypothesis, establishing the degree of hydrophobicity as the most important predictor of peptide bitterness, has been supported by other workers (Clegg et al, 1974a; Schalinatus and Behnke, 1975a, b; Adler-Nissen, 1976; Gardner, 1978; Gatfield, 1981). However, the effect of the position of an amino acid in a peptidic sequence cannot be determined by the method of Ney (1979) (Ishibashi et al, 1987a).

A correlation between threshold value and hydrophobicity value for both free amino acids and dipeptides has been established by Wieser and Belitz (1976). Their taste data, in agreement with Matoba and Hata's results (1972) quantitatively con- firmed that dipeptides are more bitter than the corresponding free amino acids, and that bitterness intensity is independent of the sequence of both amino acids. Wieser and Belitz (1975) have also found that the threshold for bitter taste decreases with increasing number of hydrophobic side chains $(\geq 3)$ in the peptide, and increases in the presence of hydrophilic side chains parallel to their polarity. This was later corroborated by Lalasidis (1978), who believed the main source of bitterness in enzymic protein hydrolysates to be peptides of more than 3 amino acids.

Among all the studies concerned with bitterness of protein hydrolysates, only Ney's (1971) extrapolated Q-rule links bitterness quantitatively to hydrophobicity. This extrapolation of the $Q$-rule to explain the presence or absence of bitterness in protein hydrolysates was proposed only by Ney (1971), and since then widely accepted.

\section{Q-rule}

Bitterness of a peptide is caused by the hydrophobic action of its amino acid side chains. An average hydrophobicity, $Q$, is obtained by summing the amino acid side chain hydrophobicities of a peptide and dividing this value by the number of amino acid residues (Ney, 1979, 1981):

$$
Q=\frac{\Sigma \Delta f}{n}
$$

Where $\Delta f=$ free energy of transfer of the side chains of the amino acid residues (hydrophobicity; cal.mol-1 according to Tanford (table I); $n=$ number of amino acid residues; $Q=$ average hydrophobicity of a peptide.

As summarised in table II peptides with $Q$-values below 1300 cal.res $^{-1}$ are not bit- 
Table I. Free energy of transfer ( $\Delta \mathrm{f}$ and $\Delta \mathrm{F}$ ) of the side chains of amino acids, representing their hydrophobicity.

Hydrophobicité des acides aminés, représentée par l'énergie libre de tranfert ( $\Delta f$ et $\Delta F$ ) de leurs chaînes latérales.

\begin{tabular}{|c|c|c|c|c|}
\hline Amino acid & Abbreviations $^{1}$ & $\begin{array}{l}R \text { groups }{ }^{2} \\
(\text { cal.mol-1) }\end{array}$ & $\begin{array}{c}\Delta f \text {-value } \\
\left(\text { cal.mol-1) }^{-1}\right)\end{array}$ & $\Delta F$-value $^{4}$ \\
\hline
\end{tabular}

Non-bitter amino acids 5

$\begin{array}{lllrrr}\text { Glutamine } & \text { Gln } & \text { Q } & 2 & -100 & +970 \\ \text { Asparagine } & \text { Asn } & \text { N } & 2 & -10 & +890 \\ \text { Glycine } & \text { Gly } & \text { G } & 2 & 0 & +810 \\ \text { Serine } & \text { Ser } & \text { S } & 2 & 40 & +420 \\ \text { Threonine } & \text { Thr } & \text { T } & 2 & 440 & +290 \\ \text { Histidine } & \text { His } & \text { H } & 3 & 500 & +690 \\ \text { Aspartic acid } & \text { Asp } & \text { D } & 4 & 540 & +610 \\ \text { Glutamic acid } & \text { Glu } & \text { E } & 4 & 550 & +510 \\ \text { Arginine } & \text { Arg } & \text { R } & 3 & 730 & +690 \\ \text { Alanine } & \text { Ala } & \text { A } & 1 & 730 & +610 \\ \text { Cysteine } & \text { Cys } & \text { C } & 2 & & +360\end{array}$

Bitter amino acids 5

$\begin{array}{llllll}\text { Methionine } & \text { Met } & \text { M } & 1 & 1300 & -660 \\ \text { Lysine } & \text { Lys } & \text { K } & 3 & 1500 & +460 \\ \text { Valine } & \text { Val } & \text { V } & 1 & 1690 & -750 \\ \text { Leucine } & \text { Leu } & \text { L } & 1 & 2420 & -1650 \\ \text { Proline } & \text { Pro } & \text { P } & 1 & 2620 & -170 \\ \text { Phenylalanine } & \text { Phe } & \text { F } & 1 & 2650 & -1520 \\ \text { Tyrosine } & \text { Tyr } & \text { Y } & 2 & 2870 & -1430 \\ \text { Isoleucine } & \text { lle } & \text { I } & 1 & 2970 & -1450 \\ \text { Tryptophan } & \text { Trp } & \text { W } & 1 & 3000 & -1200\end{array}$

${ }^{1}$ From Lehninger AL (1972) Biochemistry; ${ }^{2} R$ groups: (1) nonpolar or hydrophobic; (2) polar but uncharged; (3) positively charged (basic amino acids); (4) negatively charged (acidic amino acids) at pH 6.0-7.0, the zone of intracellular $\mathrm{pH} ;{ }^{3}$ Tandford (1962); Ney (1979); ${ }^{4}$ the greater the lowering of surface tension, the greater the hydrophobicity (Bull and Breese, 1974); ${ }^{5}$ according to table II.

ter, whereas peptides with $Q$-values higher than 1400 cal.res $^{-1}$ are bitter. If the $Q$ values lie between 1300 and 1400 cal.res ${ }^{-1}$, no prediction can be made about the peptide bitterness. This principle is vallid for molecular weights (MW) up to approximately $6000 \mathrm{Da}$; above this limit, peptides with $Q$-values higher than 1400 cal.res ${ }^{-1}$ are also not bitter.
Although Ney's (1971) semiquantitative rule can be applied to the majority of known isolated or synthetic peptides with defined amino acid composition, chain length and flavour, there are exceptions. Among these, lysine and proline have too high $Q$-values for non-bitter amino acids, the non-bitter peptide: $\beta$ : 26-28, H-lle-AsnLys-OH with a $Q$-value of 1670 cal.res $^{-1}$ 
Table II. Bitter taste of peptides in relation to their average hydrophobicity $Q$ and molecular weight (Ney, 1979).

Amertume des peptides suivant leur hydrophobicité moyenne $Q$ et leur poids moléculaire (Ney, 1979).

Non-bitter taste

$Q<1300$ cal.res $^{-1}$

Molecular weight: 100-10 $000 \mathrm{Da}$ (from one amino acid residue to many amino acid residues or protein)

$Q>1400$ cal.res $^{-1}$

Molecular weight: $6000-10000 \mathrm{Da}$

Bitter taste

$Q>1400$ cal.res $^{-1}$

Molecular weight: 100-6 $000 \mathrm{Da}$

(Pélissier et al, 1974), the dipeptide esters of L-aspartic acid and L-amino malonic acid are sweet peptides (Belitz et al, 1979) and also peptides: $\mathrm{H}$-Val-Ala-OH; H-AlaAla-Leu-OH and $\mathrm{H}$-Lys-Ala-OH are bitter although their $Q$-values are below 1300 cal.res ${ }^{-1}$ (Guigoz and Solms, 1976).

Adler-Nissen (1986a, b) has shown that the extrapolated $Q$-rule is unsubstantiated, both theoretically and empirically, and must be abandoned. According to him the $Q$-values of proteins listed by Ney (1971) are considerably overestimated. The cause of bitterness is the presence and concentration of hydrophobic peptides formed by protein hydrolysis; consequently bitterness does not depend only on the average hydrophobicity value of the hydrolysate, as implied by the extrapolated $Q$ rule. Adler-Nissen (1986b) therefore proposed a description of protein hydrolysate bitterness which takes into account the hydrophobicity distribution of peptides. From an earlier comparative study of the bitter taste of enzymic hydrolysates from cow, ewe and goat caseins, $\beta$-casein was found to be more hydrophobic than $\alpha_{s 1}$-casein, and both proteins to have an approximately uniform hydrophobicity along the pep- tide chain (Pélissier and Manchon, 1976; $\alpha_{s 1}$ : 1170 cal.res $^{-1} ; \beta: 1330$ cal.res $^{-1}$; Visser, 1977b); however, the C-terminal region of $\beta$-casein is known to be very hydrophobic and thus to have an extremely bitter taste (Shinoda et al, 1986b). It was then suggested as postulated previously (Ney, 1971; Pélissier et al, 1974), not to take into consideration the total hydrophobicity of a protein to determine whether an enzymic hydrolysate has a chance of being bitter or not. In addition, the development of bitterness was shown to be strongly influenced by the nature of the protease used (Pélissier and Manchon, 1976; Belitz and Wieser, 1985). However, earlier work on casein, lactalbumin, soya protein, zein and gliadin, which developed a bitter taste during hydrolysis with several proteinases, led Petritschek et al (1972) to conclude that the formation of a bitter taste was mainly dependent on the amino acid composition and sequence of a given protein but not on the hydrolysing enzyme.

\section{Prediction of bitterness}

According to the Q-rule it is possible to predict the bitterness of any peptide direct- 
ly from its amino acid composition and chain length. Furthermore, the risk of obtaining bitter peptides from enzymic hydrolysis of a protein can also be predicted. For example, high $Q$-value proteins such as casein and soya are prone to produce bitter peptides on enzymic hydrolysis, whereas collagen, which has a low $Q$-value, does not produce bitter peptides (Ney, 1979).

Knowing the structure of a compound, it is possible to predict its bitterness threshold. Indeed, the molecular connectivity indices, which are related to the degree of branching (hence the size and shape) of any considered chemical structure, are significantly correlated with published values for the bitterness thresholds of amino acids, peptides and their derivatives (Gardner, 1980).

Investigations of Fukui et al (1983) and Otagiri et al (1983) on natural and synthetic bitter peptides from casein hydrolysates have led them to suggest that while the $Q$ value is important to overall bitterness, bitterness intensity may not be directly related to the $Q$-value.
It seems that monitoring of the initial rates of proteolysis in stored milk may be efficient in predicting the degree of bitterness and the subsequent shelf-life of ultrahigh temperature (UHT) milk sterilised by injection of steam directly into the milk. However, some studies are still necessary to establish sensory scores corresponding to significant bitterness and to ascertain whether these scores are of commercial significance (McKellar et al, 1984).

\section{MECHANISM OF BITTER FLAVOUR FORMATION}

Since it can limit acceptance of the cheese, the development of bitterness constitutes an economic problem. The complex proteolytic enzyme system involved in the cheese ripening process is presented in figure 1. The characteristic flavour of ripened hard cheese products such as Cheddar and Gouda results from this enzymic system, which may include: 1) the proteinases associated with rennet (chymosin and pepsin); 2) other proteinases

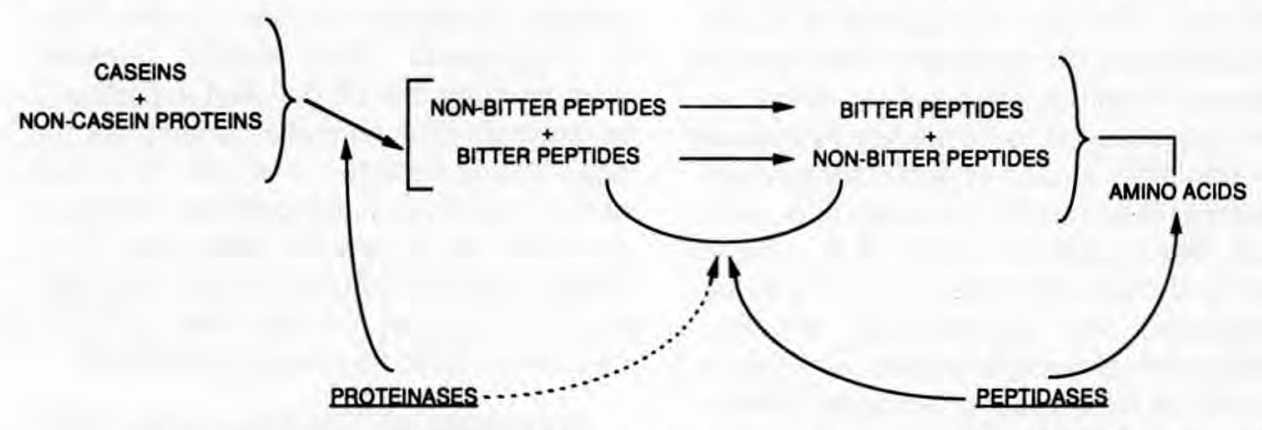

RENNET, RENNET SUBSTITUTES (MILK COAGULATOR) LACTIC STARTER ORGANISMS (ENDOPEPTIDASES) NON-STARTER ORGANISMS

LACTIC STARTER ORGANISMS (EXOPEPTIDASES, PREDOMINANTLY AMINOPEPTIDASES) MILK NON-STARTER ORGANISMS

Fig 1. Proteolytic reactions involved in bitter peptides formation in ripened hard cheese products (source: Rouseff, 1990).

Réactions protéolytiques impliquées dans la formation de peptides amers chez un fromage affiné à pâte ferme (source: Rouseff, 1990). 
used as the milk coagulant (rennet substitutes); 3 ) the proteinase/ peptidase system of the starter microorganisms; 4) the proteinase/peptidase system of the nonstarter microbial flora; 5 ) the proteinases endogenous to milk. When the delicate balance of these proteolytic reactions is not optimal, bitter peptides can accumulate to a certain level and give a bitter flavour to cheese. Many studies have tried to elucidate this complicated defect, which is affected by many factors (Lemieux and Simard, 1991), and several hypotheses have been put forward related to the formation of bitter principles in cheese.

It was established early on that the bitter components in cheese reside in the peptide fraction (Kelly, 1932; Raadsveld, 1953), and arise from interactions between bacterial and rennet proteolysis (Dinesen, 1974; Huber and Klostermeyer, 1974). However, the mechanism of bitter peptide formation/degradation in cheese ripening is difficult to elucidate, as witnessed by the conflicting reports in the literature.

A mechanism involving the combined action of rennet and bacterial proteolytic enzymes has been postulated by Czulak (1959) for the development of bitterness in cheese. Peptides released by rennet action are believed to be further hydrolysed by non-bitter strains of lactic streptococci, whereas bitter strains are unable to hydrolyse these peptides, which thus accumulate and cause the bitter taste. He further suggested that accumulation of bittertasting peptides might be due to increased activity of rennet at low $\mathrm{pH}$ levels. Hence, according to Czulak the starter streptococci do not play any significant part in the development of bitterness (fig 2). In general, the findings of many investigators agree with those of Czulak (Emmons et al, 1962b; Jago, 1962; Stadhouders, 1962).

Shorthly thereafter, it was shown that the strains of bacterial starter used for cheesemaking were linked with the bitterness of the final cheese. Emmons et al (1960a, b; 1962a) were the first to carry out a systematic investigation on the effect of manufacture conditions on the formation of cheese bitterness, and found the strain of starter organism used to be the main factor responsible. This confirmed the earlier work of Riddet et al (1932) and gave birth to a classification of starters as "bitter" and "non-bitter". In accordance with these experiments, the results obtained by Stadhouders (1962) and Czulak and Shimmin (1961) with different starters demonstrated the importance of a specific ability of streptococci to break down rennet peptides. Results obtained by Emmons et al (1962a), where bitterness was directly related to the level of trichloroacetic acid (TCA) soluble peptides and inversely related to the level of amino acids in Cheddar cheese, have demonstrated and emphasised the role of the starter organisms in the development of bitter flavour in cheese. The mechanism proposed by Emmons et al $(1962 a, b)$ involves the combined action of rennet and bacterial proteolytic enzymes, whereby peptides released by rennet action are hydrolysed further by non-bitter strains of lactic streptococci. Bitter strains, however, were presumed to be deficient in proteolytic enzymes that normally decompose the bitter-tasting peptides, and then to be unable to hydrolyse these peptides which accumulate and cause the bitter taste. Their data suggested that non-rennet enzymes, probably bacterial in origin, play an important role in Cheddar cheese proteolysis.

Manufacture of Cheddar cheese under controlled bacteriological conditions and use of gluconic acid lactone in place of starter has helped many workers to suggest that the starter by itself must be partly responsible for the development of cheese flavour (Mabbitt et al, 1955; Perry and McGillivray, 1964; Reiter et al, 1967); however, other organisms also affect cheese flavour. 


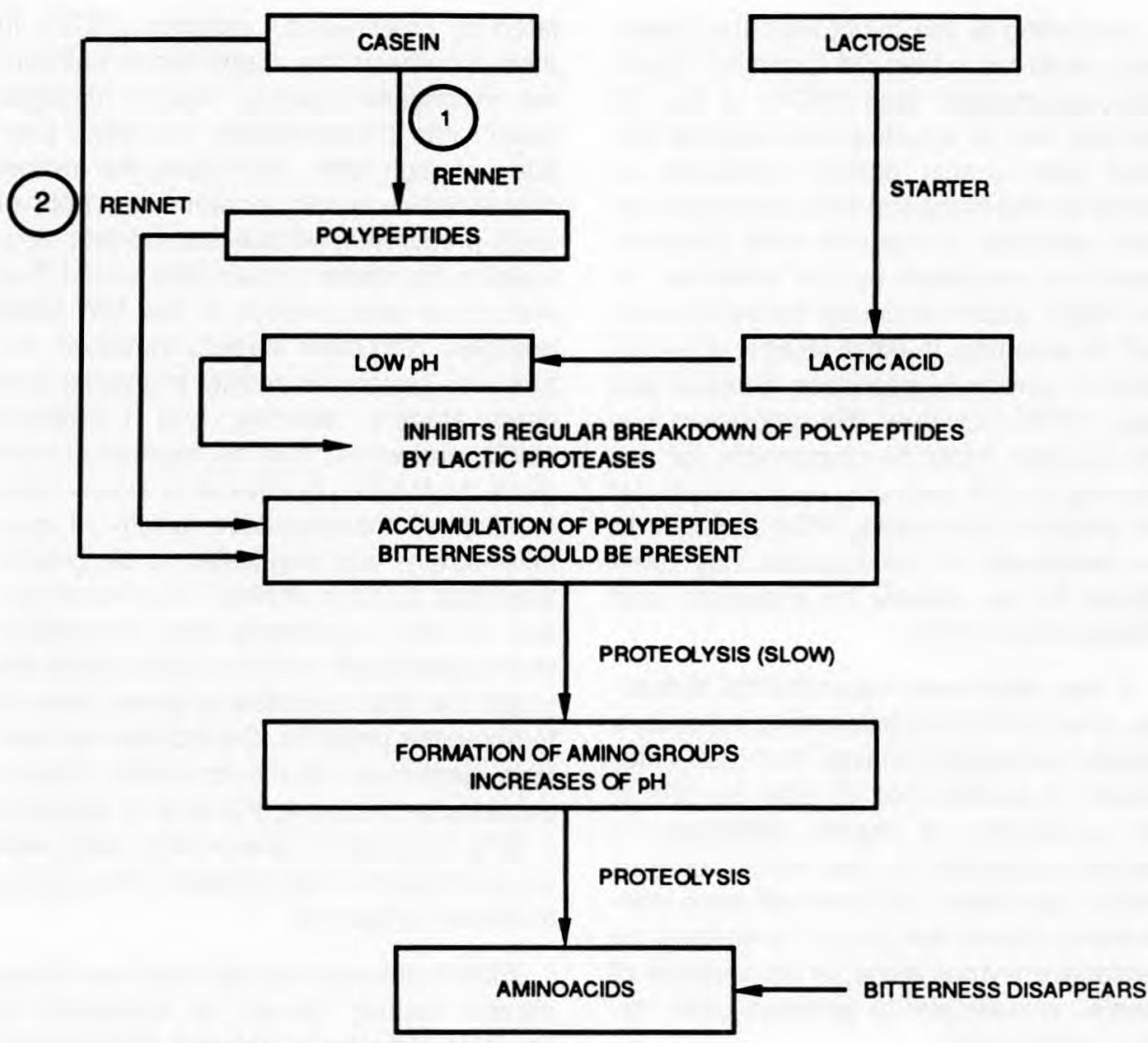

- RENNET IS THE MANOR RESPONSIBLE (PLUS LOW PH)

- PASTEURIZED MILK WOULD BE EVEN WORSE (LOW BACTERIAL COUNT)

Fig 2. Czulak's hypothesis (source: Furtado, 1984).

Hypothèse de Czulak (source: Furtado, 1984).

Based on their observations that bitter starters, in contrast to non-bitter strains, could form bitter compounds from casein in the absence of rennet, Gordon and Speck (1965a, b) suggested that a modification of Czulak's hypothesis was in order. They attributed their results to a greater proteolytic activity of bitter strains.

Although Czulak's hypothesis (1959) is generally supported by Lawrence and
Gilles' data (1969), these authors caution against its complete acceptance, suggesting that some modifications are necessary to account for the role played by fast starters (some of them can produce bitterness on their own or at least supplement that due to rennet) and the controlling influence upon the proteolytic activity of both rennet and starter by salt-in-moisture levels. 
According to the hypothesis that bitterness could result from the formation of pyrrolidonecarboxylic acid (PCA) at the $\mathrm{N}$ terminal end of a hydrophobic peptide derived from casein during proteolysis, a model for the formation and degradation of bitter peptides in cultured dairy products would be described by the presence, in non-bitter strains of Group N streptococci, and its absence, in bitter strains, of a pyrrolidone carboxylyl peptidase (Sullivan and Jago, 1970). However, the suggestion that this enzyme might be responsible for debittering rennet peptides by hydrolysis of the peptide bond joining PCA residues to the remainder of the peptides has been shown to be unlikely by Exterkate and Stadhouders (1971).

It has also been suggested by Klimovsky et al (1970) that bitter starters possess greater proteolytic activity than non-bitter strains. A positive role for bitter starters in the production of cheese bitterness is equally suggested by the results of Harwalkar and Seitz (1971), which have conclusively shown that casein proteolysis by bacterial enzymes alone, in the absence of rennin, is sufficient to produce bitter flavour components.

Recent results have been interpreted to show that all starter strains are potentially able to contribute directly to the formation of bitter-flavoured components in cheese. Indeed, intracellular proteinase and peptidase activities are present in most of the common bacteria used in cheese-making (eg Lactococcus lactis subsp lactis, Lactococcus lactis subsp cremoris; Castberg and Morris, 1976). The response of each strain to manufacturing conditions such as cooking temperature determines the likelihood of bitterness development (Lawrence et al, 1972; Lowrie et al, 1972; Martley and Lawrence, 1972).

Following these observations, an alternative hypothesis to Czulak's was formu- lated by Lowrie and Lawrence (1972). In their hypothesis the major role of calf rennet in cheese ripening was to degrade casein into predominantly non-bitter peptides of high MW. Increasing the rennet concentration would increase the pool of such precursors, whose subsequent degradation by starter proteinases would thus lead to an accumulation of low MW bitter peptides. Non-bitter starters, however, exhibit less proteolytic activity in cheese than bitter starters (Martley and Lawrence, 1972), and would thus be expected to degrade high MW peptides at a slower rate. In addition, the peptidase activity of nonbitter strains was suggested to be greater than that of bitter strains. To a lesser extent it was considered that intracellular starter peptidase could in some cases degrade the bitter peptides to amino acids or to non-bitter peptides. Contribution by bacterial peptidases to the formation of bitter peptides by reducing the size of peptides initially too large to give a bitter taste was equally thought to be of lesser importance, as shown in figure 3 .

Effects of bacteriophage infection during cheese making cannot be explained by Czulak's hypothesis. Results from experiments using milk cheese deliberately infected with bacteriophage provide evidence that the starter streptococci play a direct role in the development of cheese bitter flavour. The presence of bacteriophage prevented bitterness in cheeses made under conditions that should have given high residual rennet, negating the contention that residual rennet in cheese was important in bitter flavour production in this case (Stadhouders, 1974; Stadhouders and Hup, 1975). However, a simple explanation for the role of bacteriophage in preventing excessive development of bitter flavour is put forward with Lowrie and Lawrence's hypothesis. Thus, if starter strain enzymes give rise to bitter peptides, reduction of the starter population by massive 


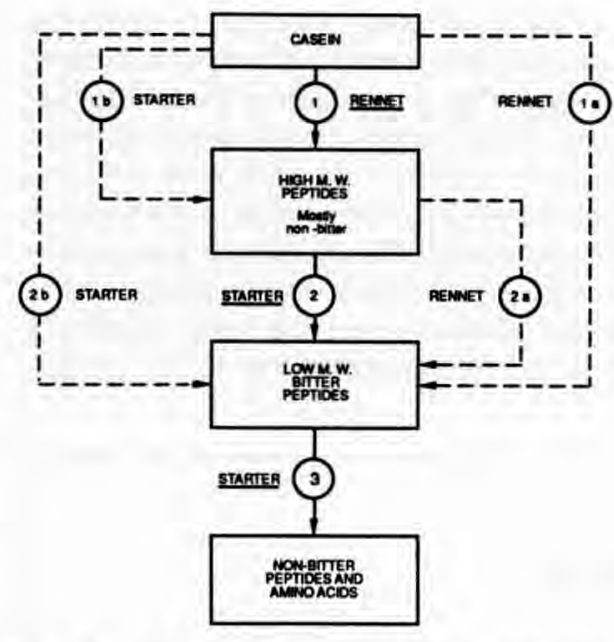

Fig 3. Lowrie and Lawrence's hypothesis (source: Lowrie and Lawrence, 1972).

Hypothèse de Lowrie et Lawrence (source: Lowrie et Lawrence, 1972).

phage attack in the last stages of cheese manufacture should reduce the potential to form bitter compounds (Lowrie, 1977).

While Lowrie and Lawrence's (1972) hypothesis has received considerable general support (Fox and Walley, 1971; Jago, 1974; Sullivan et al, 1974; O'Keeffe et al, 1975), it has never been claimed to apply to bitterness development in cheese varieties other than Cheddar, although it does appear to explain bitterness formation in Camembert cheese. It should be noted, however, that the influence of rennet on the intensity of bitterness may be less for Camembert than for Cheddar cheeses. Proteolytic activity of the surface mould flora (Penicillium caseicolum) of Camembert cheese may play a more important role in providing precursors in themselves not bitter, which are further degraded to bitter peptides by starter proteinases (Martley, 1975a, b).

In support of Lowrie and Lawrence's (1972) hypothesis, according to which bit- terness results from starter protease action on rennin produced peptides, the results obtained by Richardson and Creamer (1973) have suggested the likely precursor to be $\alpha_{s 1}$-casein.

In the meantime, studies on proteolysis rates during ripening have led Green and Foster (1974) to conclude that: 1) starter enzymes and rennet are synergistic in their action on casein and its breakdown products; and 2) starter enzymes could be responsible for at least half the cheese proteolysis.

Findings since the publication of the above-mentioned hypotheses on the existence of bitter flavour in cheese have led Stadhouders and Hup (1975) to publish a tentative scheme for the formation and breakdown of bitter peptides in Gouda cheese, paying special attention to the amount of rennet retained in the cheese. They suggested that the synergistic effect of bitter peptides produced by rennet and those produced by the specific proteinase system of bitter starters may be important for the development of bitter flavour in Gouda cheese. In their opinion, cheese may have a bitter flavour when a disproportion exists between the production of bitter peptides from casein by rennet and the breakdown of bitter compounds by the proteolytic enzymes of the starter bacteria, resulting in a concentration of bitter peptides above their threshold value(s); a nonbitter starter also has the ability to degrade bitter peptides. The degrading enzymes of non-bitter and bitter strains were both found to be active at neutral $\mathrm{pH}$; however, those of bitter strains are less active at $\mathrm{pH}$ 5.0 (Sullivan et al, 1973). Formation and breakdown are affected and influenced as shown in figure 4. Although not proven, this concept is supported by a large number of experimental results.

Although the hypothesis of Lowrie and Lawrence (1972) was developed for Ched- 
dar cheese, it is also applicable to Camembert cheese (Martley, 1975b); however, this theory does not seem to fit the results on bitterness in Gouda cheese, which has a composition and ripening conditions which are different to those of Cheddar cheese. High cooking temperatures and early salt addition to the curd in Cheddar manufacture possibly influence the proteolytic properties of starter bacteria.
Aseptically made cheeses, in which the action of starter bacteria and rennet could be separated, were used by Visser (1977a, b) to study various contributions of these enzyme systems. He was able to show that rennet and bitter starter bacteria were independently able to produce bitterness in Gouda cheese. However, the starter bacteria appeared to do this far more specifically than did rennet. According to his results,

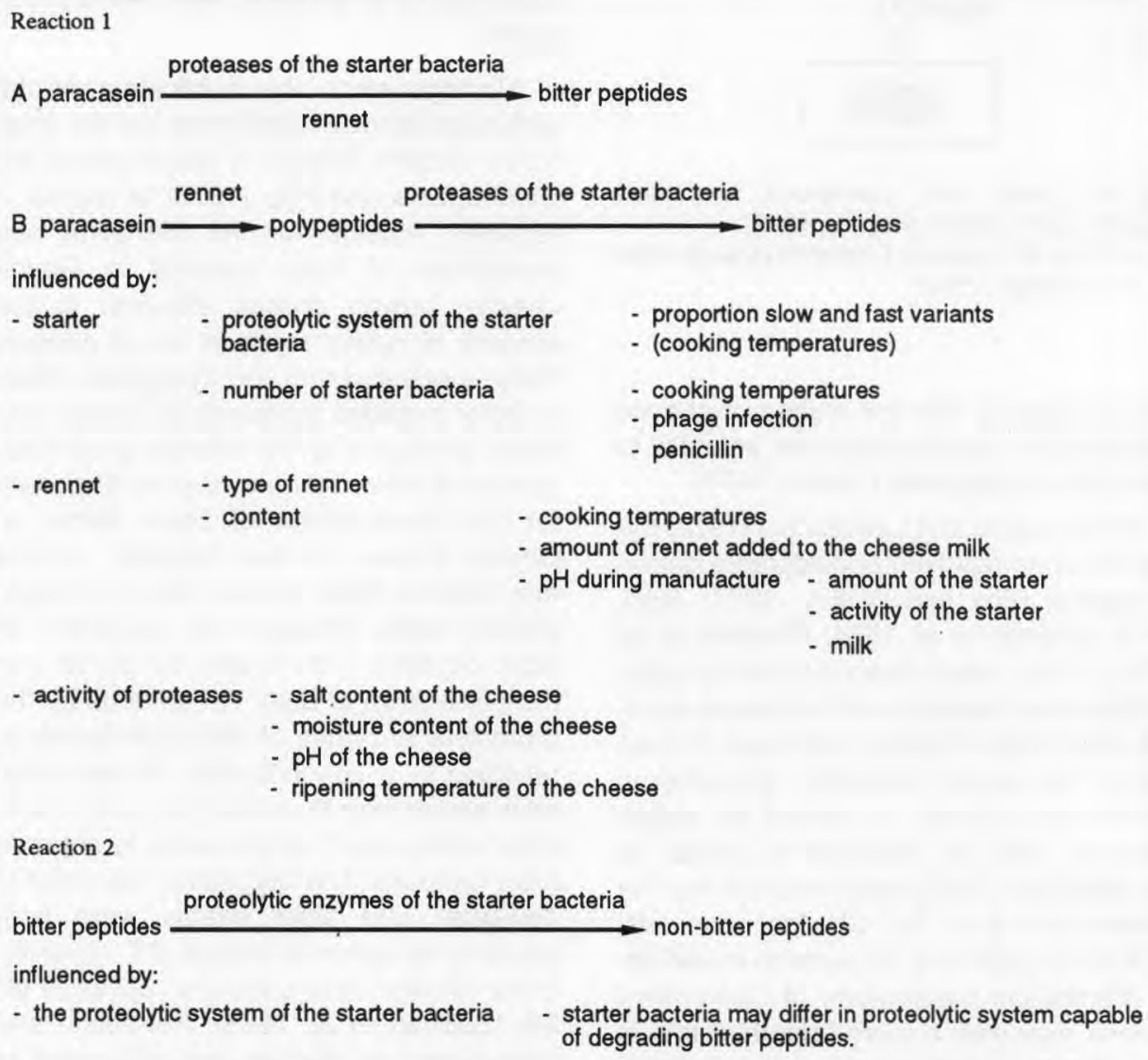

Fig 4. Tentative scheme for the formation and breakdown of bitter peptides in cheese (source: Stadhouders and Hup, 1975).

Schéma suggéré pour la formation et la dégradation des peptides amers dans le fromage (source: Stadhouders et Hup, 1975). 
bitter peptides can be degraded to a considerable extent by non-bitter starters under the conditions existing in cheese. The greater part of the observed bitterness in normal aseptic cheeses was due to the separate actions of rennet and bitter starter bacteria. According to Visser (1977a, b) a schematic representation for the different actions involved in the bitterness development in Gouda-type cheeses is given in figure 5 .

Exterkate's results (1976) concerning the non-unique responsibility of starter streptococci for bitter development in cheese were in agreement with the hypothesis of Lowrie and Lawrence (1972). Although unable to give a general explana- tion, Exterkate suggested 3 possible explanations for the development of a non-bitter cheese prepared with different types of bitter and non-bitter strains of Lactococcus lactis subsp cremoris; 1) the starter itself is unable to liberate bitter peptides at a level sufficient to exceed a certain threshold. It is thereby assumed that liberation of bitter peptides by the action of rennet alone does not result in a bitter cheese; 2) bitter peptides liberated by the action of starter proteases and rennet can be degraded efficiently by the same starter; 3) the membrane-bound endo- and exopeptidase system degrades the hydrophobic bitter peptides. The last explanation seemed to Exterkate to be the most logical for the production of a non-bitter cheese.

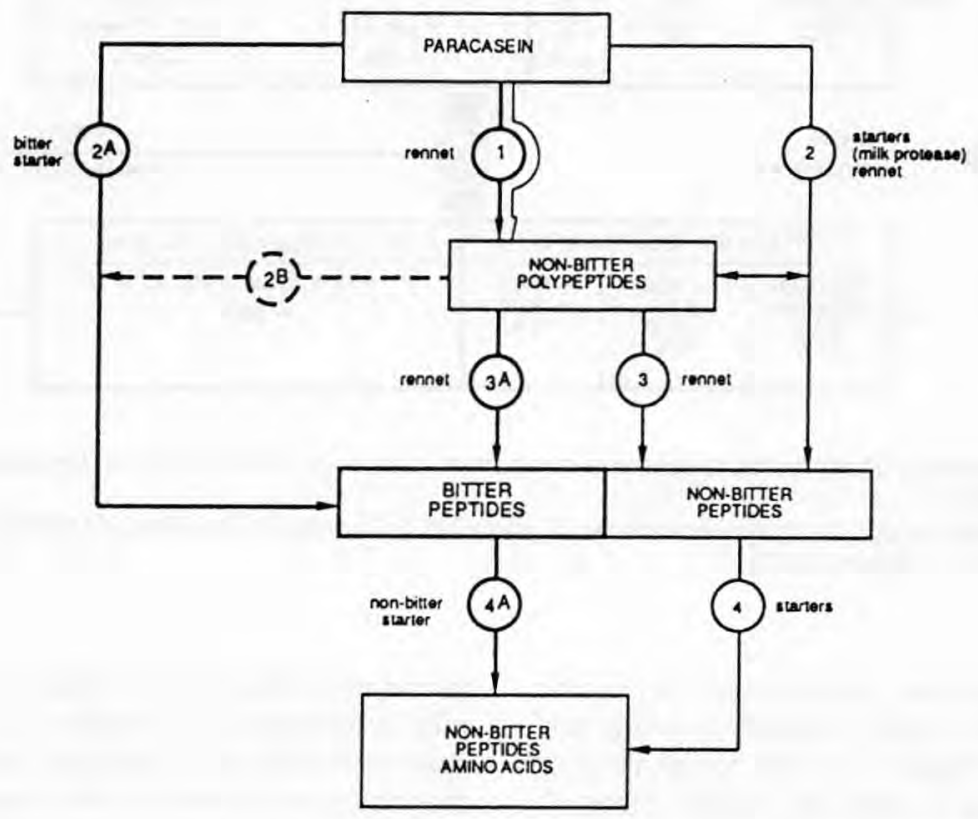

Fig 5. Mechanism for the development of bitterness in Gouda-type cheese. Thin lines: paths of general proteolysis in cheese; thick lines: paths important for bitterness development (source: Visser, 1977a).

Mécanisme d'apparition de l'amertume dans le fromage Gouda. Les lignes fines représentent la voie de la protéolyse en général dans le fromage. Les lignes épaisses représentent les voies importantes pour le développement de l'amertume (source: Visser, 1977a). 


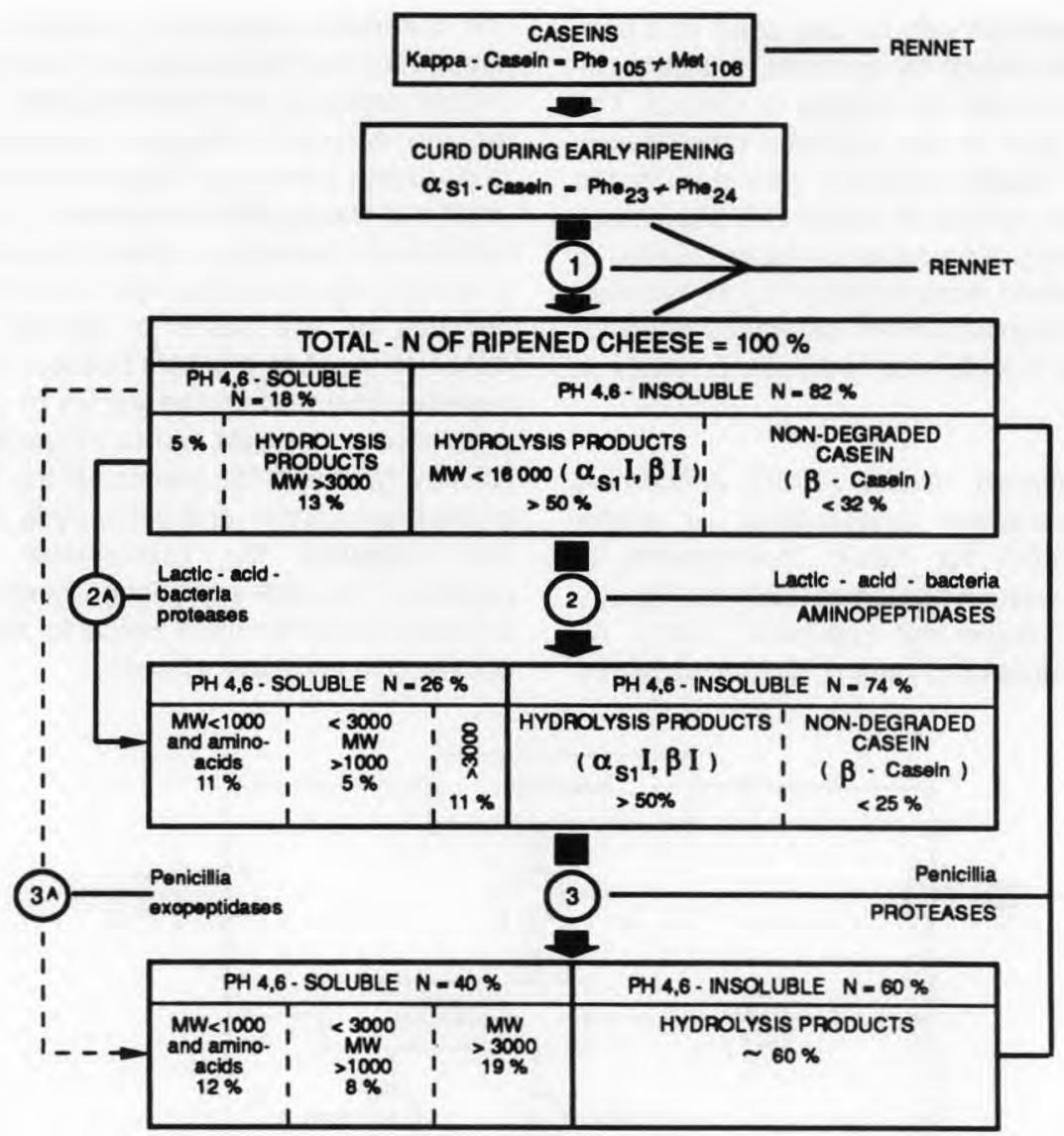

Fig 6. Tentative scheme for the breakdown mechanism of cheese protein (source: Desmazeaud and Gripon, 1977).

Représentation suggérée du mécanisme de dégradation de la protéine (caséine) du fromage (source: Desmazeaud et Gripon, 1977).

The general mechanism of protein breakdown during cheese ripening presented in figure 6 is valid for all types of cheeses up to step (2) $+(2 A)$. Steps (3) and $(3 \mathrm{~A})$ are valid for Penicillium cheese. This scheme has been proposed by Desmazeaud and Gripon (1977) from the following observations made with aseptic curds (Cheddar, blue, and cheese with controlled flora or with surface mould) ob- tained according to a technique of artificial milk acidification by addition of deltagluconic acid lactone: 1 ) rennet is the first proteolytic agent involved in the overall mechanism of casein breakdown in cheeses; it has a strong and early action on $\alpha_{\mathrm{s} 1}$ casein (Gripon et al, 1975). Rennet mainly produces peptides of high molecular weight; $3000<\mathrm{MW}<16000 \mathrm{Da}$ (Green and Foster, 1974; Gripon et al, 1975) rep- 
resenting $-50 \%$ of the total nitrogen, and does not apparently induce the release of free amino acids in the curd; thus Gripon et al (1975) have found that after 40 days of ripening, low $\mathrm{MW}$ peptides ( $\mathrm{MW}<3000$ Da) constituted only $5 \%$ of the total nitrogen content; 2) on the other hand, the action of proteolytic enzymes from lactic acid bacteria leads primarily to the formation of amino acids and short chain peptides, but also to a slight endopeptidase activity; 3) a very active proteolysis is observed in cheeses with surface mould or in blue cheese. Indeed Penicillium possesses strong endopeptidase and exopeptidase activities, resulting in the release of large amounts of amino acids; 4) milk proteases induce the breakdown of $\beta$-casein.

When too many peptides in a cheese possess the correct characteristics of size and hydrophobicity which are the main criteria for bitter flavour, the cheese is bitter (Creamer, 1979). Ney (1971) has shown

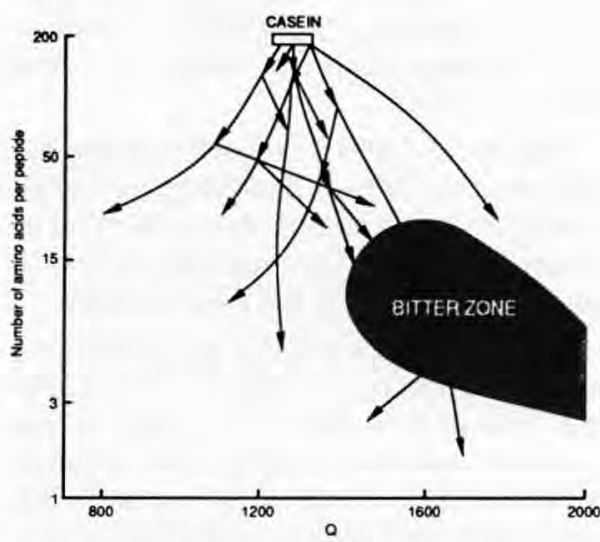

Fig 7. Possible degradation pathway of casein during cheese maturation. $Q=$ peptide hydrophobicity, according to Ney (1971) (source: Creamer, 1979).

Processus de dégradation possible de la caséine au cours de la maturation fromagère. $Q=$ hydrophobicité du peptide, d'après Ney (1971) (source: Creamer, 1979). that bitterness is related to hydrophobicity, with the more hydrophobic peptides having a more intensely bitter flavour. Only relatively small peptides, because of their solubility, have been found to be bitter (Pélissi-. er et al, 1974; Visser et al, 1975; Wieser and Belitz, 1976). A diagrammatic representation of the origin of bitterness in Cheddar cheese, from Creamer's results, is shown in figure 7; the caseins (average hydrophobicity (Bigelow's parameter): $\alpha_{\mathrm{s} 1^{-}}$, $\left[Q\right.$-value $=1170$ cal.res $\left.^{-1}\right] \alpha_{\mathrm{s} 2^{-}}, \beta-,[Q$ value $\left.=1330 \mathrm{cal}^{\text {.res }}{ }^{-1}\right]$ and $\kappa-,[Q$-value $=$ 1285 cal.res $^{-1}$ ]; Gordon and Groves, 1975), with a $Q$-value of about 1300 cal.res ${ }^{-1}$ are hydrolysed during cheese maturation through a number of intermediate steps to give a range of peptides, some bitter, some not (arrowheads). During this process the initial degradation of

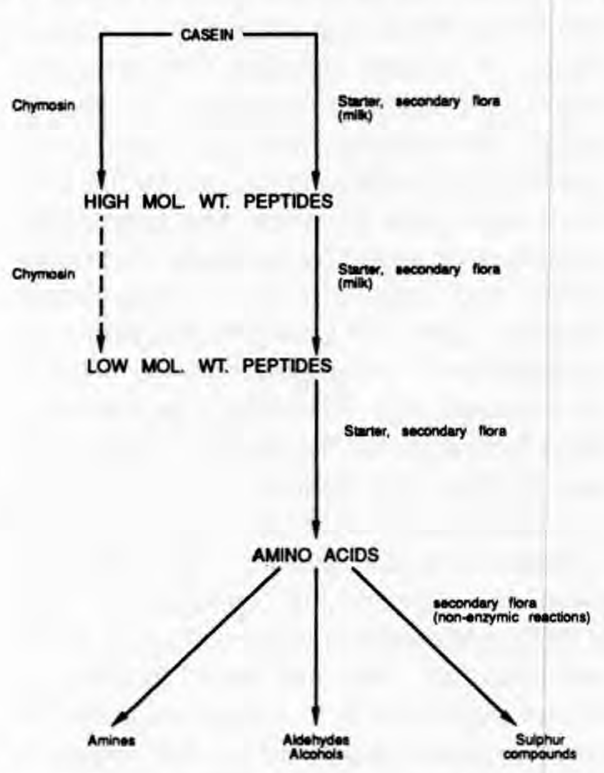

Fig 8. Breakdown of casein during cheese ripening: involvement of proteinases from various sources (source: Law, 1987).

Dégradation de la caséine au cours de l'affinage du fromage: implication de protéinases de différentes sources (source: Law, 1987). 


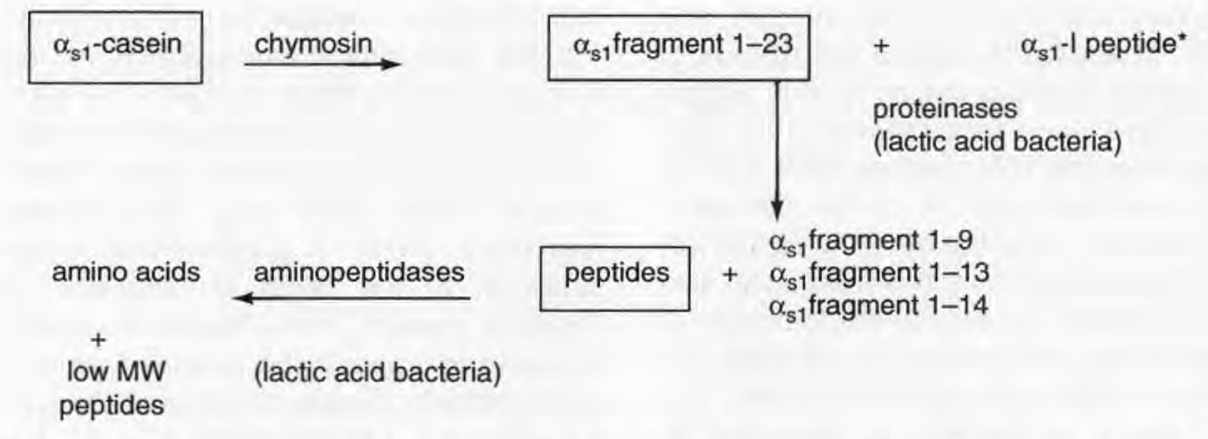

${ }^{*} \alpha_{s 1}{ }^{-1}$ peptide: is composed of residues valine ${ }_{25}$ to tryptophan $_{199}$ or phenylalanine ${ }_{24}$ to tryptophan ${ }_{199}$ (Desmazeaud and Gripon, 1977).

Fig 9. Schematic representation of the degradation of $\alpha_{\mathrm{s} 1}$-casein in cheese (source: Law, 1987). Représentation schématique de la dégradation de la caséine $\alpha_{s 1}$ dans le fromage (source: Law, 1987).

casein is more likely to be caused by the rennet enzyme (chymosin), which is important in the initial degradation of $\alpha_{\mathrm{s} 1}$-casein (fig 8), or plasmin (alkaline milk protease) which is possibly responsible for the $\beta$ casein proteolysis, whereas later (nonspecific) degradation is caused by the bacterial and mould enzymes. The zone of bitterness is bounded by solubility, hydrophobicity and peptide size. Observations made by Cliffe and Law (1990), using a reversedpliase high-performance liquid chromatography (RP-HPLC) peptide profiling technique on the water-soluble nitrogen fraction of Cheddar cheese and the removal of bitter taste from rapidly-ripened Cheddar cheese slurries have brought them to support the concept of Law (1987), presented in figure 9, and which demonstrates that the main function of starter peptidase is to further degrade the large peptides produced by the rennet to small peptides and free amino acids.

According to Visser (1981), it has been accepted that enzymes from starter bacteria play a principal role in the further breakdown of cheese protein fragments and thus in the development of cheese flavour. $\beta$-casein hydrolysis by rennet gives rise to the formation of 3 products: 1) fraction $\beta-I$, consisting of a mixture of the $\beta$-casein arginine $_{1^{-}}$alanine $_{189}$ and arginine ${ }_{1-}$ leucine $_{192}$ fragments; 2) fraction $\beta-I I$, composed of arginine $e_{1}$ - leucine $e_{165}$ and arginine $_{1}$ - glutamine ${ }_{167}$ fragments; 3 ) fraction $\beta$-III, corresponding to rarginine ${ }_{1}$ - leucine $_{139}$ residues.

Peptides $\beta$-II and $\beta$-III result from the hydrolysis of $\beta-I$ (Visser and Slangen, 1977); in addition, these authors concluded that $\beta$ casein is cleaved by chymosin in only a few definite regions of the protein chain.

Rennet has a strong and early action on $\alpha_{s 1}$-casein. Results of Gripon et al (1975) have shown that after $24 \mathrm{~h}, 40 \%$ of the $\alpha_{s 1}$-casein has been broken down, leading to the formation of the $\alpha_{s 1^{-1}}$ peptide. Free amino acids and peptides released by proteolytic enzymes such as chymosin and lactic acid bacterial proteases in cheese have been shown to contribute to the formation of cheese flavour (Guigoz and Solms, 1974; Hamilton et al, 1974; Huber and Klostermeyer, 1974; Biede and Hammond, 1979). Rennet is known to preferentially attack at the carboxylic side of pheny- 
Table III. Bitter peptides isolated from cheese.

Peptides amers isolés du fromage.

\begin{tabular}{|c|c|c|c|c|}
\hline Sample & Origin & Peptide sequence & $\begin{array}{l}\text { Hydrophobicity } \\
\text { Q cal.res }\end{array}$ & Ref \\
\hline Cheddar cheese & $\begin{array}{l}\alpha_{s 1}: 14-17 \\
\alpha_{s 1}: 17-21\end{array}$ & $\begin{array}{l}\text { H-Glu-Val-Leu-Asn-OH } \\
\text { H-Asn-Glu-Asn-Leu-Leu-OH }\end{array}$ & $\begin{array}{l}1162.5^{2} \\
1074.0^{2}\end{array}$ & $\begin{array}{l}\text { Hodges et al, } 1972 \\
\text { Richardson and Creamer, } 1973 \\
\text { Hamilton et al, } 1974 \\
\text { Hodges et al, 1972; Richardson and } \\
\text { Creamer, 1973; Hamilton et al, } 1974\end{array}$ \\
\hline & $\begin{array}{l}\alpha_{s 1}: 26-32 \\
\alpha_{s 1}: 26-33\end{array}$ & $\begin{array}{l}\text { H-Ala-Pro-Phe-Pro-Glu-Val-Phe-OH } \\
\text { H-Ala-Pro-Phe-Pro-Glu-Val-Phe-Gly-OH }\end{array}$ & $\begin{array}{l}1930.0 \\
1688.75\end{array}$ & $\begin{array}{l}\text { Richardson and Creamer, } 1973 \\
\text { Hodges et al, 1972; Hamilton et al, } 1974\end{array}$ \\
\hline $\begin{array}{l}\text { Alpkäse (Swiss } \\
\text { mountain cheese) }\end{array}$ & C-terminal $\alpha_{\mathrm{s} 1}: 198-199$ & H-Leu-Trp-OH & 2710.0 & Guigoz and Solms, 1974 \\
\hline Cheddar cheese & $\begin{array}{l}\beta: 46-67^{3} \\
\beta: 46-84\end{array}$ & $\begin{array}{l}\text { H-Gin-Asp-Lys-lle-His-Pro-Phe-Ala- } \\
\text { Gln-Thr-Gln-Ser-Leu-Val-Tyr-Pro-Phe- } \\
\text { Pro-Gly-Pro-Ile-Pro-OH } \\
\text { H-GIn-Asp-Lys-Ile-His-Pro-Phe-Ala- } \\
\text { GIn-Thr-GIn-Ser-Leu-Val-Tyr-Pro-Phe- } \\
\text { Pro-Gly-Pro-Ile-Pro-Asn-Ser-Leu-Pro- } \\
\text { Gln-Asn-Ile-Pro-Pro-Leu-Thr-Gln-Thr- } \\
\text { Pro-Val-Val-Val-OH }\end{array}$ & $\begin{array}{l}1580.45 \\
1508.5\end{array}$ & $\begin{array}{l}\text { Richardson and Creamer, } 1973 \\
\text { Hamilton et al, } 1974 \\
\text { Hamilton et al, } 1974\end{array}$ \\
\hline Butterkäse & $\beta: 61-69$ & H-Pro-Phe-Pro-Gly-Pro-Ile-Pro-Asn-Ser-OH & 1792.2 & Huber and Klostermeyer, 1974 \\
\hline Gouda & $\begin{array}{r}\beta: 84-89 \\
\beta: 193-207 \\
\text { and/or } \beta: 193-208 \\
\beta: 193-209\end{array}$ & $\begin{array}{l}\text { H-Val-Pro-Pro-Phe-Leu-GIn-OH } \\
\text { H-Tyr-GIn-GIn-Pro-Val-Leu-Gly-Pro- } \\
\text { Val-Arg-Gly-Pro-Phe-Pro-Ile-OH } \\
\text { H-Tyr-GIn-GIn-Pro-Val-Leu-Gly-Pro- } \\
\text { Val-Arg-Gly-Pro-Phe-Pro-Ile-Ile-OH } \\
\text { H-Tyr-GIn-GIn-Pro-Val-Leu-Gly-Pro- } \\
\text { Val-Arg-Gly-Pro-Phe-Pro-Ile-lle-Val-OH }\end{array}$ & $\begin{array}{l}1983.3 \\
1686.7 \\
1766.9 \\
1762.4\end{array}$ & $\begin{array}{l}\text { Visser et al, 1983b } \\
\text { Visser et al, 1983b,c } \\
\text { Visser et al, 1983b, c } \\
\text { Visser et al, 1983b, c }\end{array}$ \\
\hline
\end{tabular}

${ }^{1}$ according to Ney, $1979 ;{ }^{2} Q<1300$ cal.res $^{-1}$ and bitter taste; ${ }^{3}$ this peptide lost its bitterness by ready cyclisation of its $\mathrm{N}$-terminal glutamine to pyroglutamic acid at neutral $\mathrm{pH}$ and ionic strength of 0.1 or less. 
lalanine and leucine residues; thus, accoring to Adda et al (1982) bitter peptides obtained from casein should contain more phenylalanine and leucine than others. While $\alpha_{s 1}$-casein has nearly disappeared after 20 days of ripening, $\beta$-casein, being more resistant, has been shown to be still present in $2 / 3$ of its initial amount after 40 days of ripening. Thus the major part of intact caseins is represented by this unaltered protein (Gripon et al, 1975). Since $\alpha_{\mathrm{s} 1}$-casein is recognised as always producing more bitterness than $\beta$-casein, the relatively small amount of $\alpha_{s 1}$-casein in ewe's or goat's milk could explain why ewe or goat milk cheeses are usually less bitter than those made from cow's milk (Pélissier and Manchon, 1976). Bitter peptides isolated from cheese and listed in table III originated from both $\alpha_{s 1}$ fragment $1-23$ and $\alpha_{\mathrm{s} 1}{ }^{-1}$ peptide.

In brief, bitter peptides appear to be produced from casein by the action of rennet or chymosin as well of proteinases from the cell-wall of certain starter bacteria (Visser et al, 1983a, b). Degradation of bitter peptides occurs by the action of proteolytic enzymes from the cytoplasmic mem- brane of bacterial cells, either in concert with enzymes from the cytoplasm or without their aid. In this way, the cell wall proteinases from Lactococcus lactis subsp lactis NCDO 763 and from Lactococcus lactis subsp cremoris HP ( $\mathrm{P}_{1}$-type) have been found to be able, as is chymosin, to specifically cleave peptide bonds in the most hydrophobic part of $\beta$-casein (Monnet et al, 1986; Visser et al, 1988). The initial sites of cleavage are thus mainly located in the $\mathrm{C}$-terminal 53-residue region of the $\beta$ casein molecule. Moreover, Reid et al (1991) have also observed that the initial hydrolysis of the $\alpha_{s 1}$-casein molecule by the proteinase from Lactococcus lactis subsp cremoris SK 11 ( $\mathrm{P}_{\mathrm{II}}$-type) occurred principally at sites lying in the C-terminal part of the molecule. Other peptides, although in smaller amounts, were from the $\mathrm{N}$-terminal and the central regions of the $\alpha_{s 1}$-casein. However, they could not identify a clear consensus sequence of amino acid residues surrounding the cleavage sites. The presence of salt strongly influences the relative rate of formation and degradation of bitter peptides by starter cells. As shown by Visser et al (1983a),

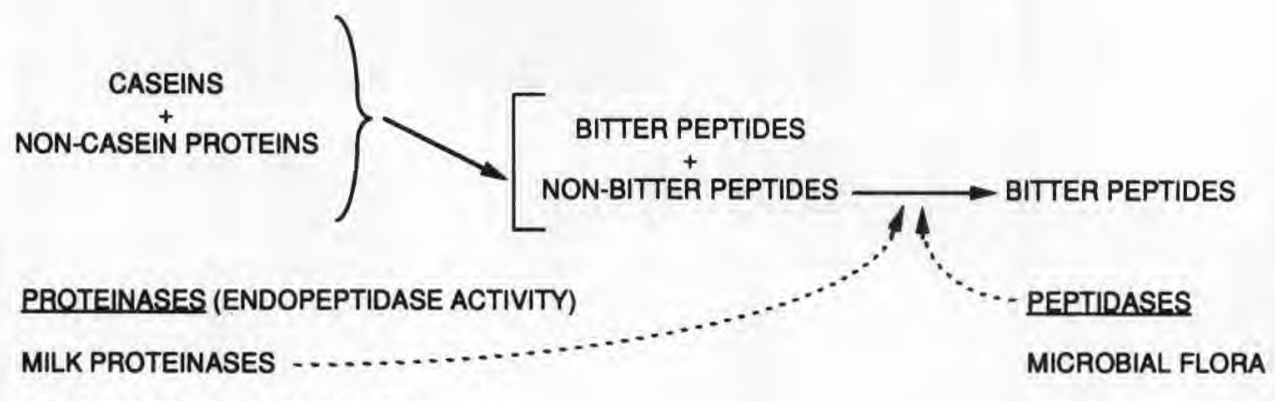

PSYCHROTROPHIC ORGANISMS

Fig 10. Proteolytic reactions involved in bitter peptide formation in ultra-high temperature (UHT) processed milk products (source: Rouseff, 1990).

Réactions protéolytiques impliquées dans la formation de peptides amers chez les produits laitiers pasteurisés à ultra-haute température (UHT) (source: Rouseff, 1990). 
salt mainly seems to prevent at least part of the bitter peptides from penetrating the cell wall and/or the membrane, and thus from becoming accessible to attack by the peptidase system situated near or in the membrane.

Although it has been extensively investigated for ripened hard cheese products, the problem of bitter taste is also associated with fresh market dairy products, yoghurt and other cultured products (ie buttermilk, sour cream) and certain ultra-high temperature (UHT) processed milk and cream which may contain heat stable enzymes (Lemieux and Simard, 1991). According to McKellar (1981), when compared to conventionally pasteurised milk, UHT milk seems to be a more suitable substrate for proteolysis and for bitterness development. The complex proteolytic system involved in the production of bitter peptides in UHT processed milk products is presented in the figure 10 (Rouseff, 1990). While a sequential proteolysis involved in the cheese ripening process would give rise to bitter peptide formation (fig 1), it would result directly, in the UHT processed milk products, from the endopeptidase activity originating from the psychrotrophic flora of raw milk. However, the role of microbial peptidases in bitterness of UHT processed milk products has not yet been investigated.

\section{ISOLATION AND IDENTIFICATION OF BITTER PEPTIDES}

To elucidate the role of peptides and amino acids and their mechanism of formation in cheese, it is necessary to determine their structure. For this purpose some peptides contributing to the bitter taste have been isolated from cheese and their structures have also been characterised (Gui- goz and Solms, 1974; Huber and Klostermeyer, 1974; Visser et al, 1983b). Results obtained by Kaminogawa et al (1986) and Pham and Nakai (1984) have proposed the reversed-phase high-performance liquid chromatography (RP-HPLC) of the water soluble fraction of cheese as a potential tool for a more objective evaluation of ripening of Cheddar cheese.

\section{Methods for the isolation of bitter peptides from bitter and non-bitter cheeses or from casein hydrolysates}

Due to their relatively large content of amino acids with hydrophobic side chains, bitter peptides are lipid-soluble and extractable with organic solvents (Raadsveld, 1953; Sullivan and Jago, 1970). Methods commonly used for isolation of bitter materials from cheese may lead to considerable loss of bitterness where glutamine peptides are involved, as they frequently require the use of solutions of low ionic strength. In neutral solutions of ionic strength $0.1 /$ or less, the glutamine cyclises readily to pyrrolidone-carboxylic acid, a change accompanied by a loss of bitter taste. Since the rapidity of cyclisation is greatly reduced at $\mathrm{NaCl}$ concentrations of 0.2 mol. $^{-1}$, it follows that high salt concentrations in cheese actually preserve the peptide in its most bitter form (Hamilton et al, 1974).

Several methods are available for extraction of peptides (water soluble nitrogen) from cheese or protein hydrolysates: $5 \% \mathrm{NaCl}$ for young cheese; buffers at $\mathrm{pH}$ 4.6 and gel electrophoresis for young and medium-aged cheeses (less than 6 months old); TCA $(2 \%$ or $12 \%)$, alcohol $(70 \%)$ and picric acid $(0.85 \%)$ for mature cheeses (Reville and Fox, 1978). Amongst them precipitation with $70 \%$ ethanol and 
exhaustive dialysis are recommended if the extract is to be characterised by electrophoresis or chromatography (Kuchroo and Fox, 1983). Further separation and isolation of peptides can be performed by RP-HPLC (Abu-Tarboush et al, 1989).

Chromatography on silica gel using an organic solvent such as propanol as a part of the eluent, provides a suitable means of purification of bitter fractions from caseins, and is also very promising for the fractionation of cheese bitter peptides. This isolation technique may be applied in combination with other methods in order to achieve complete purification of bitter peptides from cheese and other products (Gordon and Speck, 1965b; Minamiura et al, 1972b; Stadhouders, 1974; Visser et al, 1975).

Bitter peptides have been isolated from enzymic casein hydrolysates and from Butterkäse, Cheddar and Gouda cheeses by means of chromatographic techniques using Sephadex G-25 and G-50 (Hettinga and Parmelee, 1965; Schalinatus and Behnke, 1975a; Edwards and Kosikowski, 1983; Sohn and Lee, 1988) and subsequent ion-exchange chromatography on highly acid resin (Huber and Klostermeyer, 1974) or reversed-phase shromatography on a $\mathrm{C}_{18}$ (octadecyl silica) column. Bitter peptides from the activated bitter Cheddar cheese contained relatively large amounts of aliphatic, acidic, and hydroxy amino acids, but small amounts of basic and aromatic amino acids (Edwards and Kosikowski, 1983). Relatively large amounts of glutamic acid, proline, leucine, and valine, and a fairly consistent ratio of aliphatic to acidic amino acids were the factors common to most fractions isolated from Gouda cheese (Hettinga and Parmelee, 1965). It has been possible to isolate a pure nonapeptide from 2-dimensional thin-layer chromatograms of the most bitter fraction of Butterkäse cheese (Huber and Klostermeyer, 1974).
Gel filtration chromatography (using Sephadex G-25) of an alcoholic extract of bitter Cheddar cheese has shown that the most bitter fraction occurs in the molecular weight range of $2000-4000 \mathrm{Da}$ (Richardson and Creamer, 1970) or 2 000-2 500 $\mathrm{Da}$ (Richardson and Creamer, 1973). The bitter component fraction of a casein tryptic hydrolysate has a molecular weight of under $1000 \mathrm{Da}$ (Matoba et al, 1970). Ionexchange chromatography of these bitter fractions on Dowex 50W- $\mathrm{X}_{4}$ resin has enabled many peptides to be isolated from the bitter extract.

Bitter-tasting chloroform-methanol extracts (CME) have been obtained from both non-bitter and bitter Cheddar cheeses (Harwalkar and Elliott, 1965; Harwalkar, 1967; Harwalkar and Elliott, 1971; Hamilton et al, 1974). Gel filtration chromatography of CME from both cheeses was carried out on a Sephadex G-25 (or on a Sephadex LH-20 (Visser, 1977c; Visser et al, 1983b) for a bitter Gouda cheese) column into major fractions which were further resolved by paper and thin-layer chromatography and highvoltage paper electrophoresis, or by highperformance liquid chromatography (HPLC) on a reversed-phase type column (Champion and Stanley, 1982).

Action of proteases and peptidases on caseins during cheese ripening has the potential to produce a myriad of peptides. Recently, Cliffe et al (1989) have proposed a procedure that may be suitable for carrying out time course profile studies of peptides produced during the accelerated ripening of Cheddar cheese. Following its isolation by a combination of extraction with water, methanol precipitation, removal of lipid with hexane, and permeation chromatography on Sephadex G-25, the water-soluble nitrogen fraction from Cheddar cheese was then fractionated using reversedphase fast protein liquid chromatography (FPLC). However, they still have to work on their technique since the resultant 
FPLC-chromatogram obtained with a water-methanol eluent was relatively featureless when compared to that obtained by Champion and Stanley (1982). Indeed, the latter have obtained about 71 peaks when the bitter extract from Cheddar cheese coagulated with chicken pepsin was rechromatographed, following gel filtration chromatography on Sephadex G-50, on a reversed-phase HPLC column using a linear gradient from 0 to $90 \%$ methanol in water. Champion and Stanley were then able to show that the average molecular weight of the bitter fraction was $190 \mathrm{Da}$ by using gel filtration and ultracentrifugation of HPLC fractions. The bitter fraction obtained from accelerated ripening Cheddar cheese, and separated by size-exclusion HPLC (Lemieux et al, 1989), could be further fractionated into its different peptides according to the method followed by Lemieux and Amiot (1990).

\section{Identification of bitter peptides isolated from cheese}

A list of characterised bitter peptides isolated from cheese is given in table III. A bitter concentrate, with a polypeptide structure has been isolated from raw milk Gouda cheese (Raadsveld, 1953). Hydrolysis of bitter peptides has shown the presence, in large amounts, of proline, alanine, glutamic acid and valine. Unfortunately, their sequences have not been elucidated. Schalinatus and Behnke (1975a, b) have also isolated bitter peptides from Edam cheese without being able to establish their identity. Zvyagintsev et al (1972) have separated and characterised several bitter peptides from different Russian cheese varieties (eg Kostroma cheese); all these peptides contained leucine, valine, and phenylalanine residues and the presence of a cyclic $\mathrm{N}$-terminal structure was an important feature.
Bitter peptide fractions found in normal aseptic, aseptic starter-free, aseptic rennet-free and aseptic rennet- and starterfree Gouda cheeses have been shown to have a molecular weight of less than $\approx$ 1400 Da (Visser, 1977c). Obviously rennet produces relatively important amounts of small bitter peptides. Indeed, Visser et al (1983b) have come to the conclusion that the relatively slow degradation of $\beta$ casein by rennet and starter proteinases irrevocably leads to the gradual appearance of bitter fragment 193-209 as the first breakdown peptide. This peptide has also been found to be very resistant to further degradation by chymosin as well as cell wall-associated proteinases from various starters. Thus, unless suitable starter peptidases cause its degradation to non-bitter products, the bitter peptide may slowly accumulate in cheese and start to contribute to a bitter taste in time.

\section{Identification of bitter peptides isolated from casein and casein fractions}

Treatment of casein with proteolytic enzymes, rennin (Visser et al, 1975), trypsin (Matoba et al, 1969; Hill and Van Leeuwen, 1974), and papain (Clegg et al, 1974a) has been shown to frequently give rise to digests which are bitter in taste (Hettinga and Parmelee, 1965; Sullivan and Jago, 1972). Proteolytic enzymes with optimal $\mathrm{pH}$ on the neutral or alkaline side generally gave more bitterness as compared with enzymes with an acidic optimal $\mathrm{pH}$ (Minamiura et al, 1972b). Bitterness has been attributed to the presence in milk protein enzymic digests, of peptides composed of unmodified fragments of one or more of the parent caseins (Matoba et al, 1970; Sullivan and Jago, 1972).

The same bitter tasting hydrolysate resulted from each $\alpha-, \beta$-, and $\gamma$ - fraction of 
Table IV. Bitter peptides isolated from $\alpha_{s 1}$-casein.

Peptides amers isolés de la caséine $\alpha_{s 1}$.

\begin{tabular}{|c|c|c|c|c|}
\hline \multicolumn{2}{|l|}{ Origin } & Peptide sequence & $\begin{array}{l}\text { Hydrophobicity } \\
\text { Q, cal.res }\end{array}$ & Ref \\
\hline \multicolumn{2}{|l|}{$\begin{array}{l}\alpha_{s 1}: 21-23 \\
\alpha_{s 1}: 23-34\end{array}$} & $\begin{array}{l}\text { H-Leu-Arg-Phe-OH } \\
\text { H-Phe-Phe-Val-Ala-Pro-Phe-Pro-Glu²-Val-Phe-Gly- } \\
\text { Lys-OH }\end{array}$ & $\begin{array}{l}1933.3 \\
1833.3\end{array}$ & $\begin{array}{l}\text { Pélissier et al, } 1974 \\
\text { Matoba et al, } 1970 \\
\text { Helbig et al, } 1980\end{array}$ \\
\hline \multicolumn{2}{|l|}{$\alpha_{s 1}: 23-34$} & $\begin{array}{l}\text { H-Phe-Phe-Val-Ala-Pro-Phe-Pro-Gln²-Val-Phe-Gly- } \\
\text { Lys-OH } \\
\text { (BP-II) }\end{array}$ & 1779.3 & $\begin{array}{l}\text { Matoba et al, 1969, } 1970 \\
\text { Belitz and Sparrer, } 1971 ; \text { Mercier et al, } 1971 \\
\text { Hill and Van Leeuwen, } 1974\end{array}$ \\
\hline \multirow{2}{*}{\multicolumn{2}{|c|}{$\begin{array}{l}\alpha_{s 1}: 26-33 \\
\alpha_{s 1}: 29-32\end{array}$}} & H-Ala-Pro-Phe-Pro-Gin-Val-Phe-Gly-OH & 1607.5 & Hamilton et al, 1974 \\
\hline & & H-Pro-Gin-Val-Phe-OH & 1715.0 & Pélissier et al, 1974 \\
\hline \multicolumn{2}{|l|}{$\alpha_{s 1}: 91-100$} & H-Tyr-Leu-Gly-Tyr-Leu-Glu-Gln-Leu-Leu-Arg-OH & 1660.0 & Hill and Van Leeuwen, 1974 \\
\hline \multirow{2}{*}{\multicolumn{2}{|c|}{$\begin{array}{l}\alpha_{s 1}: 92-99 \\
\alpha_{1}: 94-100\end{array}$}} & H-Leu-Gly-Tyr-Leu-Glu-Gln-Leu-Leu-OH & 1625.0 & Pélissier et al, 1974 \\
\hline \multirow{2}{*}{\multicolumn{2}{|c|}{$\begin{array}{l}\alpha_{s 1}: 94-100 \\
\alpha_{s 1}: 95-99\end{array}$}} & H-Tyr-Leu-Glu-Gin-Leu-Leu-Arg-OH & $\begin{array}{l}1615.7 \\
15420\end{array}$ & Hamilton et al, 1974 \\
\hline \multirow{2}{*}{\multicolumn{2}{|c|}{$\begin{array}{l}\alpha_{s 1}: 99-101 \\
\alpha_{s 1}: 143-149\end{array}$}} & $\begin{array}{l}\text { H-Leu-Glu-Gin-Leu-Leu-OH } \\
\text { H-Leu-Arg-Leu-OH }\end{array}$ & $\begin{array}{l}1542.0 \\
1856.7\end{array}$ & $\begin{array}{l}\text { Mercier et al, } 1971 \\
\text { Pélissier et al, } 1974\end{array}$ \\
\hline \multirow{2}{*}{\multicolumn{2}{|c|}{$\begin{array}{l}\alpha_{s 1}: 143-149 \\
\alpha_{s 1}: 145-150\end{array}$}} & H-Ala-Tyr-Phe-Tyr-Pro-Glu-Leu-OH & 2101.4 & $\begin{array}{l}\text { Pelissier et al, } 1974 \\
\text { Pélissier et al, } 1974\end{array}$ \\
\hline & & H-Phe-Tyr-Pro-Glu-Leu-Phe-OH & 2293.3 & Belitz and Sparrer, 1971 \\
\hline \multicolumn{2}{|l|}{$\alpha_{s 1}: 145-151$} & H-Phe-Tyr-Pro-Glu-Leu-Phe-Arg-OH & 2070.0 & Mercier et al, 1972; Hill and Van Leeuwen, 1974 \\
\hline \multicolumn{2}{|c|}{$\alpha_{s 1}: 167-179$} & $\begin{array}{l}\text { H-Val-Pro-Leu-Gly-Thr-Gln-Tyr-Thr-Asp-Ala-Pro-Ser- } \\
\text { Phe-OH }\end{array}$ & 1304.6 & Pélissier et al, 1974 \\
\hline \multicolumn{2}{|l|}{$\alpha_{s 1}: 198-199$} & H-Leu-Trp-OH & 2710.0 & Hill and Van Leeuwen, 1974 \\
\hline \multirow[t]{5}{*}{ Mixture of $\alpha_{\mathrm{s} 1}$ : } & & The mixture is bitter & & \\
\hline & $14-17$ & H-Glu-Val-Leu-Asn-OH & 1162.5 & Matoba et al, 1970; Hodges et al, 1972 \\
\hline & $17-21$ & H-Asn-Glu-Asn-Leu-Leu-OH & 1074.0 & Richardson and Creamer, 1973 \\
\hline & $26-33$ & H-Ala-Pro-Phe-Pro-Gin²-Val-Phe-Gly-OH & 1607.5 & \\
\hline & $26-33$ & H-Ala-Pro-Phe-Pro-Glu²-Val-Phe-Gly-OH & 1688.75 & \\
\hline \multicolumn{2}{|l|}{$\alpha_{s 1}$-casein $^{3}$} & $\begin{array}{l}\text { [Leu-Trp-Leu-Trp] or cyclo (Trp-Leu-Trp-Leu), [cyclo } \\
\text { (Leu-Trp)]* }\end{array}$ & 2710.0 & $\begin{array}{l}\text { Minamiura et al, } 1972 a \\
\text { Fukui et al, 1983; *Kanehisa et al, } 1984\end{array}$ \\
\hline \multirow{2}{*}{\multicolumn{2}{|c|}{$\begin{array}{l}\alpha_{\mathrm{s} 1} \text {-casein } 4(145-148) \\
\alpha_{\mathrm{s} 1} \text { - } \text {-asein }^{4}(149-150)\end{array}$}} & H-Phe-Tyr-Pro-Glu-OH & 2172.5 & Belitz and Sparrer, 1971 \\
\hline & & H-Leu-Phe-OH & 2535.0 & Belitz and Sparrer, 1971 \\
\hline
\end{tabular}

1 According to Ney, $1979 ;{ }^{2}$ residue 30 in the $\alpha_{s 1}$-casein is shown as glutamine by Richardson and Creamer (1973), but is considered to be a glutamic acid residue by Matoba et al (1970) and Hodges et al (1972). However, Nagao et al (1984), by characterising bovine caseins at mRNA levels by cloning cDNAs have assigned glutamate instead of glutamine for position $30 ;{ }^{3}$ possibly from the C-terminal sequence of $\alpha_{s 1}$-casein (Mercier et al, 1971 ); ${ }^{4}$ degradation of $\alpha_{s 1}$ : 145-150 with the action of thermolysine. 
Table V. Bitter peptides isolated from $\beta$-casein.

Peptides amers isolés de la caséine $\beta$.

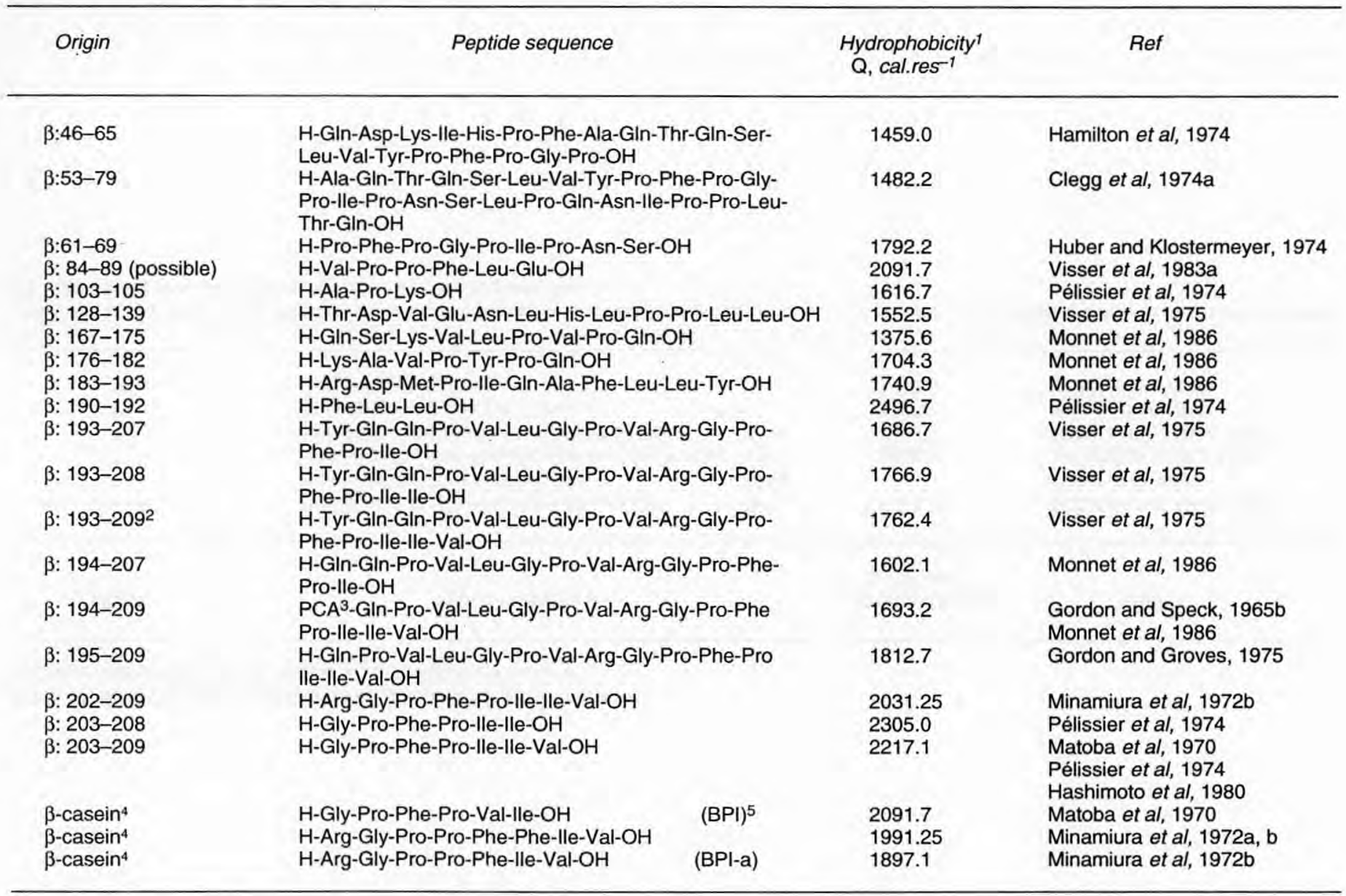

1 According to Ney, $1979 ;{ }^{2}$ the conclusion of Pélissier et al (1974) that the C-terminal fragment $193-209$ of $\beta$-casein would be a non-bitter peptide, is not in accordance with the observations of Visser et al (1975); ${ }^{3}$ PCA: pyrrolidonecarboxylic acid, a derivative formed by cyclization of $\mathrm{N}$-terminal glutamine (Sullivan and Jago, 1970); ${ }^{4}$ possibly from the C-terminal sequence of $\beta$-casein; this $p$ otein (variant $A^{2}$ ) has the highest hydrophobicity among caseins (Ribadeau-Dumas et al, 1972). No amino sequence of these peptides can be found in the structure of the casein but they are very similar to the C-terminal portion of the $\beta$-casein (Hashimoto et al, 1980 ); ${ }^{5}$ Hashimoto et al (1980) assumed the structure of the natural peptide isolated by Matoba et al (1970) to be H-Gly-Pro-Phe-Pro-lle-lle-Val-OH and not H-Gly-Pro-Phe-Pro-Vallle-OH. However, they could not verify their assumption. 
Table VI. Bitter peptides isolated from $\alpha_{\mathrm{s}_{2}}$-casein and casein fractions.

Peptides amers isolés de la caséine $\alpha_{s 2}$ et fractions de caséine.

\begin{tabular}{|c|c|c|c|c|}
\hline Origin & Peptide sequence & & $\begin{array}{l}\text { Hydrophobicity } \\
\text { Q, cal.res }\end{array}$ & Ref \\
\hline $\begin{array}{c}\alpha_{\mathrm{s} 2}: 174-181 \\
\star \\
\star \\
\star \\
\star \\
\star \star\end{array}$ & $\begin{array}{l}\text { H-Phe-Ala-Leu-Pro-GIn-Tyr-Leu-Lys-OH } \\
\text { H-Leu-Val-Pro-Arg-Tyr-Phe-Gly--- } \\
\text { H-Val-Tyr-Pro-Phe-Pro-Pro-Gly-lle-Asn-His-OH } \\
\text { H-Val-Glu-Val-Phe-Ala-Pro-Pro-Phe-OH } \\
\mathrm{Glu}_{2}-\mathrm{Pro}_{3}, \mathrm{Val}_{1}, \mathrm{Leu}_{1}, \mathrm{Tyr}_{4}, \mathrm{Phe}_{1} \\
\mathrm{Glu}_{4}, \mathrm{Pro}_{2}, \mathrm{Tyr}_{2}, \mathrm{Phe}_{2}\end{array}$ & $\begin{array}{l}\text { BPIII } \\
\text { BPI-b } \\
\text { BPI-c }\end{array}$ & $\begin{array}{l}1888.75 \\
1853.0 \\
1900.0 \\
2266.7 \\
1848.0\end{array}$ & $\begin{array}{l}\text { Matoba et al, } 1969,1970 \\
\text { Fukui et al, } 1983 \\
\text { Minamiura et al, 1972b } \\
\text { Belitz and Sparrer, } 1971 \\
\text { Helbig et al, } 1980 \\
\text { Helbig et al, } 1980\end{array}$ \\
\hline
\end{tabular}

1 According to Ney, $1979 ; \cdot$ bitter peptides which cannot be located as residues of the sequences of $\alpha_{s 1}-$ or $\beta$-caseins; * bitter fractions isolated from the butanol extract of the activated carbon used in debittering pronase-hydrolysed skim milk. 
the casein complex submitted to a tryptic enzymic hydrolysis. According to Carr et al (1956), this polypeptide may have a cyclic portion with a side-chain carrying a Cterminal: H-Leu-Val-Glu-Leu-OH. A bitter peptide isolated from milk cultures of $\mathrm{LaC}$ tococcus lactis subsp cremoris has been found to contain 19 amino acid residues (1 arginine, 2 glutamic acid, 2 glycine, 2 isoleucine, 2 leucine, 1 phenylalanine, 5 proline and 4 valine). However, it is not known whether this bitter peptide results from the accumulation of secondary breakdown products, or is the product of a coupling reaction involving peptides and amino acids (Gordon and Speck, 1965b). According to its amino acid composition, this bitter peptide has been reported to be very similar to $\beta$-casein fragments $193-209$ and 193-207 (and/or 193-208) isolated from Goudatype cheese by Visser et al (1983b). Cell wall proteinases can also hydrolyse caseins and supply peptides. As demonstrated by Monnet et al (1986), the cell wall proteinase from Lactococcus lactis subsp lactis NCDO 763 is able, as is chymosin, to specifically cleave peptide bonds in the most hydrophobic part of $\beta$-casein and thus to liberate 5 identified bitter peptides: $\beta$ : 167175; $\beta$ : 176-182; $\beta$ : 183-193; $\beta$ : 194-207 and $\beta$ : 194-209. Bitter peptides isolated from $\alpha_{\mathrm{s} 1^{-}}, \beta-\alpha_{\mathrm{s} 2^{-}}$caseins and casein fractions are listed in tables IV, V and VI respectively.

\section{Synthesis of bitter peptide fragments from $\beta$ - and $\alpha_{s 1}$-caseins}

Studies on the structure-taste relationship of synthetic bitter peptides have been carried out chiefly by Japanese workers. Peptides were synthesised by the conventional liquid phase synthetic procedure. In simplifying the structure of peptides they wanted to learn more about the mechanism of bitterness. Synthesised $\beta$ - and $\alpha_{\mathrm{s} 1}$-casein bit- ter peptide fragments without analogues and peptides with simplified structure (with the exception of $\mathrm{H}$-Arg-Pro-Phe-Phe-OH) are shown in table VII. Thus a strongly bitter heptapeptide, H-Gly-Pro-Phe-Pro-lleIle-Val-OH has been synthesised by Hashimoto et al (1980) and was found to be indistinguishable from the natural peptide $\beta$ : 203-209, isolated from a tryptic hydrolysate of Hammersten casein by means of chromatography, amino acid analyses, and mass spectrometric measurements. In addition, they assumed the structure of the natural peptide isolated by Matoba et al (1970) to be $\beta$ : 203-209 and not BPI (HGly-Pro-Phe-Pro-Val-Ile-OH); however, they could not verify their assumption.

In order to elucidate the relationship between the structure of heptapeptide BPI-a (H-Arg-Gly-Pro-Pro-Phe-lle-Val-OH) and its bitter taste, it has been synthesised, along with many analogues, by many workers (Fukui et al, 1983; Miyake et al, 1983; Otagiri et al, 1983, 1985; Nosho et al, 1985). BPI-a is one of the most bitter compounds, comparable with phenylthiourea and quinine, and the results of both taste and circular dichroism measurements (Miyake et al, 1983), have shown its bitter taste to be caused by the spatial structure of the molecule conferred by the L-proline residue. The study of Shinoda et al (1985b) has confirmed that the number of hydrophobic amino acids alone cannot control the strength to bitterness in peptides, while Nosho et al (1985) have observed that, in addition to the hydrophobicity of the molecule, the detailed structure is also important for an increase in bitterness.

Ishibashi et al (1988a) have been able to investigate in detail the effect of the amino acid side chains on bitterness. For this purpose, they have synthesised many oligopeptides in which the constituent amino acids are systematically changed in terms of the hydrophobicity of the side chain. They have also studied extensively the sig- 
Table VII. Synthesized $\beta$ - and $\alpha_{\mathrm{s} 1}$-casein bitter peptide fragments. Séquences de peptides amers synthétiques des caséines $\beta$ et $\alpha_{s 1}$.

\begin{tabular}{|c|c|c|c|c|c|}
\hline Origin & Peptide sequence & $\begin{array}{l}\text { Hydrophobicity } \\
\text { Q, cal.res }\end{array}$ & $T V^{2}$ & Rcap & Ref \\
\hline$\beta: 60-66$ & H-Tyr-Pro-Phe-Pro-Gly-Pro-lle-OH & 2335.7 & & 6.3 & $\begin{array}{l}\text { Kanehisa et al, } 1984 \\
\text { Shinoda et al, } 1985 \mathrm{a}, \mathrm{b} ; 1986 \mathrm{a}, \mathrm{b}\end{array}$ \\
\hline$\beta: 61-66$ & H-Pro-Phe-Pro-Gly-Pro-Ile-OH & 2246.7 & 0.44 & 2.3 & Shinoda et al, 1985a; $1986 \mathrm{a}, \mathrm{b}$ \\
\hline$\beta: 61-67$ & H-Pro-Phe-Pro-Gly-Pro-lle-Pro-OH & 2300.0 & 0.25 & 4.0 & $\begin{array}{l}\text { Kanehisa et al, } 1984 \\
\text { Shinoda et al, } 1985 \mathrm{a}, \mathrm{b} ; 1986 \mathrm{a}, \mathrm{b}\end{array}$ \\
\hline$\beta: 82-88$ & H-Val-Val-Val-Pro-Pro-Phe-Leu-OH & 2197.1 & 0.14 & 7.1 & Shinoda et al, 1985a; $1986 a$ \\
\hline$\beta: 82-90$ & H-Val-Val-Val-Pro-Pro-Phe-Leu-GIn-Pro-OH & 1988.9 & 0.38 & 2.6 & Shinoda et al, $1985 a$ \\
\hline$\beta: 196-201$ & H-Pro-Val-Leu-Gly-Pro-Val-OH & 1840.0 & 0.50 & 2.0 & Shinoda et al, 1985b; 1986b \\
\hline$\beta: 196-209$ & $\begin{array}{l}\text { H-Pro-Val-Leu-Gly-Pro-Val-Arg-Gly-Pro-Phe- } \\
\text { Pro-lle-Ile-Val-OH }\end{array}$ & 1949.3 & 0.0149 & 67.0 & Shinoda et al, 1985b; 1986a, b \\
\hline$\beta: 200-209$ & H-Pro-Val-Arg-Gly-Pro-Phe-Pro-lle-lle-Val-OH & 2056.0 & 0.004 & 250.0 & Shinoda et al, 1985b; 1986a, b \\
\hline$\beta: 202-209$ & H-Arg-Gly-Pro-Phe-Pro-Ile-Ile-Val-OH & 2031.25 & 0.004 & 250.0 & Shinoda et al, 1985b; 1986a, b \\
\hline$\beta:$ 203-209 & H-Gly-Pro-Phe-Pro-lle-lle-Val-OH & 2217.1 & $0.17-0.34$ & $5.88-2.94$ & Hashimoto et al, 1980 \\
\hline B: 204-209 & H-Pro-Phe-Pro-Ile-Ile-Val-OH & 2586.7 & 0.125 & 8.0 & Shinoda et al, 1985b \\
\hline$\beta$-casein ${ }^{4}$ & H-Arg-Gly-Pro-Pro-Phe-lle-Val-OH & 1897.1 & 0.05 & 20.0 & $\begin{array}{l}\text { Fukui et al, } 1983 \\
\text { Miyake et al, } 1983 \\
\text { Otagiri et al, 1983, } 1985 \\
\text { Nosho et al, } 1985\end{array}$ \\
\hline & H-Arg-Pro-Phe-Phe-OH ${ }^{5}$ & 2162.5 & 0.04 & 25.0 & Nosho et al, 1985 \\
\hline & H-Arg-Gly-Pro-Pro-Phe-lle-OH & 1931.7 & 0.025 & 40.0 & Shinoda et al, 1986a \\
\hline$\alpha_{s 1}$ - casein $^{6}$ & cyclo (Leu-Trp) & 2710.0 & 0.063 & 15.87 & $\begin{array}{l}\text { Shiba and Nunami, } 1974 \\
\text { Fukui et al, } 1983\end{array}$ \\
\hline
\end{tabular}

${ }^{1}$ According to Ney, $1979 ;{ }^{2} \mathrm{TV}=$ threshold value; ${ }^{3}$ Rcaf $=$ the ratio to caffeine; ${ }^{4}$ possibly from the C-terminal sequence of $\beta$-casein (Ribadeau-Dumas et al, 1972); ${ }^{5}$ this tetrapeptide produces a bitter taste that corresponds to that of BPla; however, its molecular weight is only about half that of BPla; ${ }^{6}$ possibly from the C-terminal sequence of $\alpha_{s 1}$-casein (Mercier et al, 1971). 
nificance of linear and branched side chains in $n$-leucine and $n$-valine on peptide taste, and the influence of structural change to the side chain of the amino acid. Results of these different structural analyses will be resumed in the next section.

\section{STRUCTURE OF BITTER PEPTIDES OR RELATIONSHIP BETWEEN THE CHEMICAL STRUCTURE AND TASTE}

Threshold values of bitter substances are much lower than those of sweet, sour and salty substances. Indeed, the values for humans are as follows: strychnine 1.6 $\mu \mathrm{mol} . \mathrm{I}^{-1}$, picric acid $3.7 \mu \mathrm{mol} . \mathrm{I}^{-1}$, quinine 8 $\mu \mathrm{mol} . \mathrm{I}^{-1}$, nicotine $19 \mu \mathrm{mol} . \mathrm{I}^{-1}$, caffeine 700 $\mu \mathrm{mol} . \mathrm{I}^{-1}$ and theobromine $750 \mu \mathrm{mol} . \mathrm{I}^{-1}$. To clarify the physicochemical mechanism of bitter taste sensation liyama et al (1986) have investigated the effect of bitter substances on a model membrane system of taste reception, and found their type of response to be different from that observed with other taste stimulants.

As mentioned by Kubota and Kubo (1969) a bitter compound must contain at least one "unit" of bitter taste. This "unit" consists of a $\mathrm{DH}$ group (eg, $\mathrm{OH}, \mathrm{CHO}$ $\mathrm{COCH}_{3}, \mathrm{CHCOOCH}_{3}$ and $\mathrm{CHCO}$ groups) and an $A$ group (eg, carbonyl groups such as $\mathrm{CHO}, \mathrm{CO}, \mathrm{COOH}$ and a double bond such as $\mathrm{C}=\mathrm{C}-\mathrm{O}-$ ); these proton-donor and proton-acceptor groups in the mulecule must be within a distance of about $1.5 \AA$. The order of the interorbital $A-D H$ distance would then require the binding of bitter molecule to the receptor to be very strong to overcome the tendency for the molecule to adopt an intramolecularly $\mathrm{H}$-bonded state. From their work, Birch and Lee (1976) have concluded that no distinct interorbital distances could yet be established for bitterness but that $A$-DH systems could suffice to explain bitterness in some types of sugar analogues.
A bitter receptor can be excited only if the chemical and steric properties of the molecule match exactly the polar and nonpolar contact zones of the receptor. Bitter compounds need only one polar group which may be electrophilic or nucleophilic, and a hydrophobic group; moreover, the hydrophobic contact zone of the receptor has been found to be suitable for molecules up to a dimension of about $10-12 \AA$ by $16-18 \AA$ by $5 \AA$. Changes in molecules caused by introducing an additional functional group or by removing a functional group may not only influence the intensity of taste (bitterness) but also its quality (changes from bitter to sweet or vice versa) (Belitz et al, 1983).

Knowing that like other biological processes, taste occurs by a substance and receptor interaction, Shinoda and Okai (1985) have proposed a model for the bitter taste receptor of the gustation cell. As seen in figure 11, 2 functional groups are necessary to produce bitterness, a pair of 2 hydrophobic groups or of hydrophobic and basic groups (Tamura et al, 1990). The $B^{\prime}$ site has to be open to produce bit-
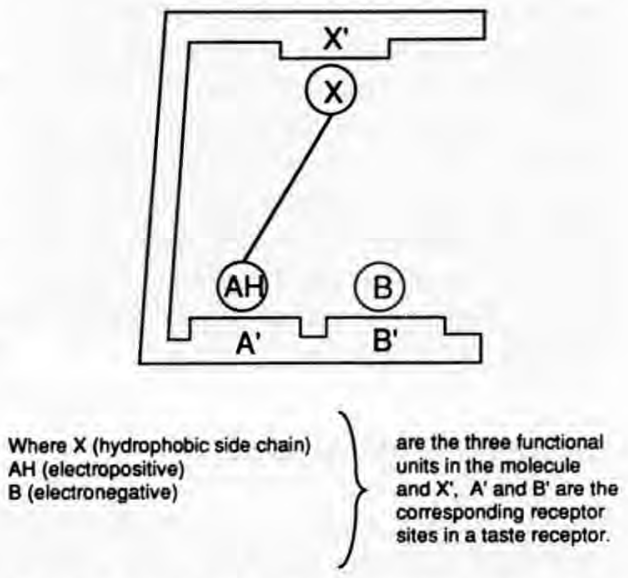

Fig 11. Bitter taste receptor model proposed by Shinoda and Okai (1985).

Modèle proposé par Shinoda et Okai (1985) pour un récepteur du goût amer. 


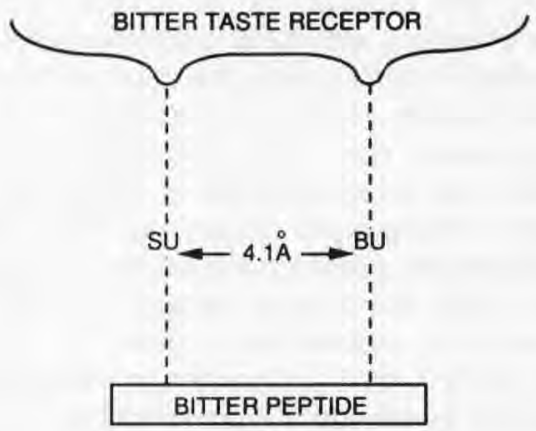

Where BU: binding unit (hydrophobic group) SU: stimulating unit (hydrophobic or basic group)

Fig 12. Scheme of binding of bitter peptide with bitter taste receptor (source: Ishibashi et al, 1988c).

Schéma représentant la liaison entre le peptide amer et le récepteur du goût amer (source: Ishibashi et al, 1988c).

terness. AH-X components can thus be regarded as being bitter substances.

Supporting the preceding hypothesis, Ishibashi et al (1988c) have postulated a mechanism for bitter taste sensibility in peptides. The intensity of bitterness is thus assumed to be dependent on the features of the binding and stimulating units (the primary and the secondary bitter taste determinant sites, respectively) and on the distance between the units $(\mathrm{AH}-\mathrm{X})$ estimated to be $4.1 \AA$ (fig 12). Small changes in this distance would probably affect the intensity of bitterness.

\section{Bitterness of amino acids}

Produced as a result of enzymic protein hydrolysis, the bitter taste may occur as an off-flavour during cheese maturation, and should therefore be considered undesirable. Some authors (Belitz et al, 1979; Gat- field, 1981) have established a relationship between the structure of the amino acids and bitter taste: 1) Configuration at the $\alpha$ C-atom is important for the amino acid taste quality; while the natural L-forms of the hydrophobic amino acids are bitter to humans, the D-enantiomorphs are sweet. For both types of taste the presence of a hydrophobic area is essential, and the difference in taste sensation between the Land $\mathrm{D}$-enantiomorphs is due to the different spatial arrangement of $-\mathrm{NH}_{2}$ and $-\mathrm{COOH}$ relative to the hydrophobic side chain. 2) The length of the side chain $R$ is important both for the quality and intensity of taste (Ishibashi et al, 1988a): up to $R=E t$, D- and L-amino acids are sweet, while $R$ > Et causes bitter taste of increasing intensity in the L-series and increasing sweet taste in the D-series. 3) Amino acids with branched side chains are significantly more bitter than the corresponding compounds with unbranched chains of equal C-number. 4) The presence of an ammonium group on the amino acid makes it able to be alkylated, arylated or acylated. Thus $\mathrm{N}$-acetylation or esterification have been shown to abolish the sweet taste and to increase the bitter taste. However, the carboxylate group in an amino acid is not essential for bitter taste since its substitution with hydrogen or its esterification or amidation does not decrease the bitter taste. 5) Aromatic side chains generally increase bitter taste intensity. L-phenylalanine and Ltryptophan, for instance, are among the most bitter amino acids; in fact tryptophan is the most hydrophobic of all common amino acids and is approximately half as bitter as caffeine (Solms et al, 1965). According to Okai (1976) the hydrophobic side group of these aromatic amino acids may act as one of the bitter taste binding sites (fig 11). 6) The type and position of substitution of polar components in the side chain can also influence bitterness. Bitter taste is usually decreased by addi- 
tion of amino, hydroxy, carboxylic or carboxamide groups, and the greater the distance between the $\alpha$-amino group and the polar component, the smaller the contribution to bitter taste. 7) Apart from steric factors, the side chain hydrophobicity and hence the total amino acid hydrophobicity plays the most significant role in creating a perception of bitter taste (Ishibashi et al, 1988a). Threshold values of bitter amino acids leucine, tryptophan, phenylalanine, isoleucine, arginine, valine, methionine and histidine are listed in table VIII (Kirimura et al, 1969; Fujimaki et al, 1970a; Matoba et al, 1970).

Table VIII. Threshold values of bitter amino acids (from Kirimura et al, 1969).

Valeurs seuil des acides aminés amers (source : Kirimura et al, 1969).

\begin{tabular}{lcccc}
\hline $\begin{array}{c}\text { Amino } \\
\text { acids }\end{array}$ & $\mathrm{R}_{\text {caf }}{ }^{1}$ & $\begin{array}{c}\text { TV }^{2} \\
\text { mmol. }{ }^{-1}\end{array}$ & $\begin{array}{c}\text { Bitterness } \\
(\%)\end{array}$ \\
\hline His & - & - & 0.02 & $* *$ \\
Arg. HCl & - & - & 0.03 & $* * *$ \\
Met & - & - & 0.03 & $* * *$ \\
Val & 0.05 & 19 & 0.04 & $* * *$ \\
Arg & 0.04 & 25 & 0.05 & $* * *$ \\
lle & 0.04 & 25 & 0.09 & $* * *$ \\
Phe & 0.05 & 19 & 0.09 & $* * *$ \\
Trp & - & - & 0.09 & $* * *$ \\
Leu & 0.05 & 20 & 0.19 & $* * *$ \\
Pro & 0.08 & 13 & 0.30 & $* * *$ \\
\hline
\end{tabular}

1 The ratio of amino acid bitterness to caffeine, $R_{\text {cal }}$. was obtained by dividing the threshold value (TV) of caffeine (1.0) by those of amino acids (eg. Pro has a bitter taste equivalent to 0.08 that of caffeine) (Tamura et al, 1990): ${ }^{2}$ TV $=$ threshold value $\left(\mathrm{mmol} .1^{-1}\right.$ and $\left.\%\right) ;{ }^{3}$ asterisks denote relative taste intensities. The taste intensities of individual amino acids were estimated by comparing them to that of solutions of $\mathrm{NaCl}$ at concentrations of 0.2 to $5.123 \mathrm{~g}$ per $100 \mathrm{ml}$.

' Le quotient d'amertume des acides aminés par rapport à la caféine $R_{c a f}$ est obtenu en divisant la valeur seuil (TV) de la caféine $(1,0)$ par celles des acides aminés (Pro a un goût amer équivalent à 0,08 fois celui de la caféine) (Tamura et al, 1990); ${ }^{2} \mathrm{TV}=$ valeur seuil (mmol..$^{-1}$ et \%); 3 les astérisques indiquent lintensité relative du goût. Les intensités des goûts des acides aminés sont estimées par comparaison avec celle d'une solution de $\mathrm{NaCl}$ à des concentrations de 0,2$5,123 \mathrm{~g} / 100 \mathrm{ml}$.

\section{Bitterness in peptides}

Although hydrophobicity (including the hydrophobic side chain, the kind and number of hydrophobic groups and the $Q$-value) has been previously shown to be the main factor involved in the determination of peptide bitterness, other factors such as the sequence and spatial structure are also suspected to play a role. However, these last 2 factors have not yet been fully studied.

With the exception of aspartic acid dipeptide esters (Wieser and Belitz, 1976), the bitter taste of peptides does not seem to depend on the configuration at the $\alpha-C$ atoms of the amino acids involved, but on the amino acid sequence. However the literature on this subject is somewhat controversial (Arai et al, 1970a; Matoba et al, 1970; Matoba and Hata, 1972; Sullivan and Jago, 1972; Shiraishi et al, 1973; Gardner, 1978; Shinoda et al, 1985b). An essential requirement for bitter taste is the presence of at least one hydrophobic side chain (Matoba and Hata, 1972; Wieser and Belitz, 1976; Belitz et al, 1979; Ishibashi et al, 1987b).

Bitterness has been found in peptides ranging in size from 2 to 23 residues. It has been observed that dipeptides containing neutral amino acids with either large alkyl groups $\left(\geq C_{3}\right)$ or a combination of large and small $\left(\leq \mathrm{C}_{2}\right)$ alkyl groups, neutral and aromatic amino acids, or neutral and basic amino acids, are bitter (Kirimura et al, 1969). One cause of bitterness lies in peptides, containing a high proportion of hydrophobic side-chains (proline, leucine and valine), as well as of glutamic acid, with a ratio of aliphatic to acidic amino acids of 0.8-1.3 (Edwards and Kosikowski, 1983), but these do not fully explain all the bitterness (Manning and Nursten, 1985).

As shown by their solubility in organic solvents, lipid solubility or hydrophobicity is the common property of all the bitter pep- 
tides so far isolated. In contrast to sweettasting compounds, for which 2 polar groups complemented by a hydrophobic group are essential (bipolar-hydrophobic concept), bitter compounds require only 1 polar group, together with a hydrophobic moiety (monopolar-hydrophobic concept) (Belitz and Wieser, 1985).

It was earlier suggested by Ney (1971) that hydrophobicity was the only factor determining whether a peptide would be bitter or not; as mentioned above, it is possible to qualitatively predict the degree of peptide bitterness with the aid of Ney's $Q$ value, which, based on Tanford's studies, represents the average hydrophobicity of the amino acid side chains (Belitz et al, 1979; Wieser and Belitz, 1976; Otagiri et al, 1985). However, the accuracy of the estimation of bitter taste thresholds is limited because steric parameters, although important for the intensity of bitter taste, are not reflected in the total peptide hydrophobicity. Bitter peptides with an average hydrophobicity of less than 1300 have thus been isolated (Kirimura et al, 1969; Fujimaki et al, 1970a).

The nature of the terminal amino acids in bitter peptides has been shown to have some significance. At least terminal leucine, isoleucine, phenylalanine, lysine and valine appear important for peptide bitterness (Kirimura et al, 1969; Sullivan and Jago, 1972; Schalinatus and Behnke, 1975b). A hydrophobic terminal residue in peptides functions as a bitter taste determinant site, and its location at the Cterminus has been reported by Okai (1976) to make the peptide more bitter than when at the $\mathrm{N}$-terminus. Hydrophobicity from leucine, phenylalanine or tyrosine residues causes marked peptide bitterness. Intensity of bitterness is greater when leucine and phenylalanine are located at the C-terminus than at the $\mathrm{N}$ terminus or in the middle of peptides (Ishi- bashi et al, 1988b), and also when their content is increased in peptides. Similarly, L-tyrosine gives rise to a bitter taste in peptides. However, the effect of tyrosine location is not as definite as in the case of phenylalanine peptides, probably due to the presence of a hydroxyl group in the tyrosine molecule (Ishibashi et al, 1987a, b). The bitter taste of peptides linking the Cterminal valine has been shown to be appreciably less than for those linking the $\mathrm{N}$ terminal valine (Ishibashi et al, 1988a).

The contribution of L-proline residues to bitterness has been recognised from the study of synthetic di- and tripeptides. To give bitter taste to a dipeptide, a proline residue needs its partner amino acid to contain more than 5 carbons, and by means of the combination with other amino acids proline promotes bitter taste intensity (Shiraishi et al, 1973; Shinoda et al, 1986a); thus the most significant role of a proline residue in peptide bitterness does not depend on its hydrophobic character. Instead, conformational alteration of the peptide molecule by folding of the peptide backbone due to the imino ring of the proline residue ensures that the peptide molecule will form a suitable conformation for the bitter taste receptor. When the proline residue is located at the $\mathrm{N}$-terminus the bitter taste is weak or absent. To produce bitter taste in proline peptides, 2 determinant sites (binding unit and stimulating unit) are essential and they should be adjacent in the steric conformation of peptides (Ishibashi et al, 1988b). A high content of proline dispersed along the peptide chain renders the peptide resistant to normal endo- and exopeptidase attack (Sullivan et al, 1973); bitter peptides have thus been found to be more resistant to enzymic degradation (Schalinatus and Behnke, 1975b). An arginine residue contiguous to proline, such as in Arg-Pro, Gly-Arg-Pro and Arg-Pro-Gly has resulted in a strong bitter taste, and in- 
creasing the number of amino acids in the peptides whose structure is $(\operatorname{Arg})_{x}$ (Pro $)_{y}$ (Phe) $z$ (where $x=1-2 ; y$ and $z=1-3$ ) resulted in a synergistic effect for bitter taste (Otagiri et al, 1985).

Linking of 1 or 2 amino acids (glycine, alanine, valine, leucine) to the $\alpha$ - or $\omega$ carboxyl groups of aspartic or glutamic acid has proved that although aspartic acid and glutamic acid are less perceptibly bitter (table VIII), they are able to elicit a bitter taste when they compose the peptides (Ohyama et al, 1988). Being a tasteless amino acid residue in peptides, glycine is limited to the role of spacer (Ishibashi et al, $1987 \mathrm{a}, 1988 \mathrm{~b})$. It is suggested, in order to strengthen peptide bitterness, that highly hydrophobic amino acids (tryptophan, isoleucine, tyrosine, phenylalanine; see table I) concentrate in the C-terminal, and basic amino acids (arginine, lysine, histidine) in the N-terminal of the molecule. Moreover, the presence of the valine residue, although increasing bulkiness and hydrophobicity, is less effective than that of basic amino acids. The limiting threshold value for bitterness of peptides composed of only neutral and hydrophobic amino acids

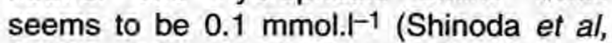
1985a, 1986a, b). Cyclopeptides are more bitter than the corresponding open-chain peptides and taste intensity increases with hydrophobicity (Belitz and Wieser, 1985). Studies on various kinds of model bitter peptides have led Otagiri et al (1985) to report that bitterness potency generally increases with increasing molecular weight.

Size, amino acid composition and $\mathrm{N}$ terminal residues of medium length peptides (4-10 residues) isolated from bitter Cheddar, Edam and Gouda cheeses at 4 months of age satisfy the requirements for bitterness (Sullivan and Jago, 1972).

The sensation of bitterness is caused by chemical compounds with a hydrophobic region and one hydrophilic group spaced
$0.3 \mathrm{~nm}$ apart. This configuration is obeyed, among others, by the hydrophobic natural $\mathrm{L}$-amino acids and peptides therefrom (Belitz et al, 1979). Peptide bitterness decreases upon complete hydrolysis to free amino acids. Since in hydrophobic peptides the amino and carboxyl groups are blocked and peptide bonds formed, they are considerably more bitter than the corresponding mixture of free amino acids; thus a peptide molecule with a high content of amino acids with hydrophobic side chains will also develop a bitter taste (Matoba and Hata, 1972; Adler-Nissen, 1984). Bitter peptides have been found to possess a higher content of aromatic (phenylalanine and tyrosine), aromaticheterocyclic (tryptophan) and also heterocyclic (proline and histidine) amino acids (Roland et al, 1978). A protein such as casein is not bitter in itself, however, hydrolysis to peptides of varying size results in exposure of hydrophobic side chains which can interact with taste buds, increasing the bitter flavour. Bitterness is comparatively weak when a hydrophobic amino acid is in a terminal position, and weakest when it is free. Thus, an extensive hydrolysis will usually result in decreased overall bitterness (Adler-Nissen, 1986a). Out of 3 major fractions of casein, $\alpha_{\mathrm{s} 1^{-}}, \beta-$, and $\kappa$-, only $\alpha_{\mathrm{s} 1}$-casein is degraded to any extent at the $\mathrm{pH}, \mathrm{NaCl}$ and calcium lactate levels found in Cheddar cheese (Richardson and Creamer, 1970; Sullivan and Jago, 1972; Pélissier and Ribadeau-Dumas, 1976). $\beta$ Casein is more resistant to enzymic degradation because of its high content in proline residues (Phelan et al, 1973; Visser and de Groot-Mostert, 1977), and peptides derived from $\beta$-casein are therefore likely to be present at much lower levels. Since the $\mathrm{C}$-terminal sequence of $\beta$-casein has been shown to possess an extremely bitter taste (Shinoda et al, 1985a), a higher content of hydrophobic amino acids in $\beta$ casein would thus make it a greater poten- 
tial source of bitter peptides than $\alpha_{s}$ casein. The $\beta$-casein component in a mixed system consisting of casein, rennet (or chymosin) and proteolytic enzymes from Lactococcus lactis subsp cremoris HP-starter bacteria has been shown to be the main source of bitter peptides (Visser et al, 1983a, b). It was earlier proposed that bitter peptides originated from $\beta$ casein (Sullivan and Jago, 1972); however, contrasting with the generally accepted belief that $\beta$-casein is the major source of bitter peptides in dairy products, it was found that cheese made from milk containing the $A$ variant of $\alpha_{s 1}$-casein is less bitter because the $\mathrm{N}$-terminal region of this protein is not degraded in the same way as in variants $B$ and $C$, this would then suggest that bitter peptides present in normal Cheddar cheese largely originate from $\alpha_{\mathrm{s} 1}$-caseins $B$ or $C$ (Richardson and Creamer, 1973) and not from $\beta$-casein. Knowing that $\alpha_{\text {s1 }}$-casein is almost nonexistent in goat milk and that products from total goat casein are always much less bitter than those from total cow casein, Pélissier and Ribadeau-Dumas (1976) have suggested $\alpha_{s 1}$-casein to be the main source of bitter peptides.

A bitterness map has been constructed from the $\beta$-casein sequence by Shinoda et al (1986a) for its potential use in food industry. These authors also suggest from the analysis of bitter peptides: $\beta: 61-69 ; \beta$ : $46-47 ; \beta: 53-79$, that some of the good bitter cheese components are derived from the middle portion of $\beta$-casein. In addition, it is noteworthy that these 3 bitter peptides isolated from cheese included a common hydrophobic fragment, $\beta$ : 61-67: H-Pro-Phe-Pro-Gly-Pro-lle-Pro-OH. A structure in which the hydrophobic side chains are directed towards the interior of the particle with one or more hydrophilic groups pointing towards the solvent has been suggested for $\beta$-casein bitter peptide fragments 193-209 and 193-207 (and/or
193-208), which combine high average hydrophobicity with good water solubility (Visser et al, 1983b).

Since it effectively blocks normal aminopeptidase breakdown, the presence of the $\mathrm{N}$-terminal pyrrolidonecarboxylyl residue has been found to make bitter peptides accumulate in dairy products (Sullivan et al, 1973). Peptides containing a cyclised glutamate end-group have been shown to be bitter while removal of it made them lose their bitterness (Sullivan and Jago 1970; Fox and Walley, 1971). On the contrary, Hamilton et al (1974) observed that high salt concentrations in Cheddar cheese preserved the peptide $\beta$ : $46-67$ in its most bitter form, because $\mathrm{N}$-terminal glutamine could not be easily converted to the pyrrolidone carboxylic acid (PCA) form.

Infrared spectroscopy has shown the structure of 2 kinds of bitter peptide prepared from enzymically and nonenzymically hydrolysed casein to be similar (Tokita, 1969a). This unique structure was formed partly by cyclic amide, $\gamma$-lactam or other lactam structures consisting of $\mathrm{NH}$ and $\mathrm{CO}$ groups produced by dehydration and hydrolysis during proteolysis.

Phosphopeptides and bitter peptides are both known to be resistant to proteolytic attack, while purified phosphopeptides from rennet casein hydrolysates or from Cheddar cheese extracts do not possess bitterness. However, since peptides prepared from the same sources were solely bitter when completely free of bound phosphate then phosphopeptides should not be considered responsible for the bitterness in Cheddar cheese (Dulley and Kitchen, 1972).

Structural information from studies on bitterness (determined organoleptically by a panel evaluation) of synthesised peptides (BPI-a, retro BPI-a, BPI-c, several analogs and a bitter peptide consisting of tryptophan and leucine) is given below. 


\section{H-Arg-Gly-Pro-Pro-Phe-lle-Val-OH (BPI-a)}

The characteristic conformation of peptide $\mathrm{BPI}-\mathrm{a}$, with a sequence slightly different from that of the $\mathrm{C}$-terminal tail of $\beta$-casein (202-209), is responsible for its strong bitter taste, which requires the presence of at least 6 amino acid residues and one L-proline residue at the 3 - position; however, the number of hydrophobic amino acid residues at the C-terminal is not important (Otagiri et al, 1983). On the other hand, results from Otagiri et al (1984) suggest both basic amino acid residues in N-terminal position and hydrophobic amino acid residues in the Cterminal moiety to be required for the intense bitterness of BPI-a; although Minamiura et al (1972b) showed earlier that this peptide is still bitter even upon removal of the C-terminal valine and isoleucine residues, and the $\mathrm{N}$-terminal arginine. The strong bitterness exhibited by BPI-a was also found to depend on both basicity and side chain length of the $\mathrm{N}$-terminal amino acid (Kanehisa and Okai, 1984). Synthesis of retro-BPI-a (possessing a reverse sequence of $\mathrm{BPI}-\mathrm{a}$ ) and its fragments has led Shigenaga et al (1984) to find that, in order for the bitter taste to be exhibited by BPI-a, the spatial structure of the molecule is more important than the position of the basic and hydrophobic moieties. In addition to hydrophobicity, spatial structure may thus be another factor in increasing the bitterness potency of BPI-a (Otagiri et al, 1985). Studies of Fukui et al (1983) and Otagiri et al (1983) on this peptide have also led them to conclude that specific amino acids as well as overall conformation of BPI-a is important to the intensity of bitterness. In addition, they suggest that at least 6 amino acids are necessary, and that glycine and Lproline are important for bitterness in this peptide.
It has been suggested by Aoyagi and Izumiya (1977) and Fukui et al (1983) to convert the sequence of the heptapeptide $\mathrm{BPI}-\mathrm{a}$ to the correct $\mathrm{C}$-terminal sequence of $\beta$-casein, the octapeptide $\beta: 202-209$. However, studies of synthetic peptides have helped to prove that the structure of the peptide BPI-a does not need to be converted to Ribadeau-Dumas et al (1972) formula: H-Arg-Gly-Pro-Phe-Pro-lle-lle-Val$\mathrm{OH}$; this could be explained by another kind of variant in $\beta$-casein (Kanehisa et al, 1984).

\section{H-Val-Tyr-Pro-Phe-Pro-Pro-Gly-OH (BPI-c)}

It has been found that proline residues in positions 5 and 6 are necessary for the strong bitterness of BPI-c. The basic nature of the C-terminal and the hydrophobic nature of its $\mathrm{N}$-terminal also contribute to the bitter taste of this peptide. In addition to the individual amino acids, some specific molecular configuration, ie tertiary structure, is also required for the strongly bitter taste of BPI-c, which has a bitter taste 20 times stronger than that of caffeine ie $R_{\text {cat }}$ $=20$ (Kanehisa, 1984) .

\section{A bitter peptide consisting of tryptophan and leucine}

A bitter peptide isolated from casein digests (Minamiura et al, 1972b), with the putative chemical structure cyclo (L-leucylL-tryptophyl-L-Leucyl-L-tryptophyl) (Minamiura et al, 1972a), has also been synthesised for structural study. Results have shown that this peptide is a diketopiperazine, and its structure has been proved to be cyclo (L-leucyl-L-tryptophyl) (Shida and Nunami, 1974). 


\section{DISAPPEARANCE OF BITTERNESS IN PROTEOLYTIC PRODUCTS}

\begin{abstract}
Although bitterness has to be accepted as a necessary consequence of proteolysis it can nevertheless be mitigated by masking, removal, or prevention.
\end{abstract}

\section{Masking or reduction of bitterness}

Generally, enzymic protein hydrolysates have a bitter taste which may be one of the main factors limiting the spread of their utilisation in food. However, a low level of bitterness can, to a certain degree, be accepted as a necessary consequence of proteolysis because it may be masked by the use of different products: 1) bitterness has been masked through the use of glutamic acid and glutamyl rich oligopeptides (Desmazeaud and Hermier (1972); 2) addition of polyphosphates has successfully masked the bitterness of casein hydrolysates (Tokita, 1969b); 3) gelatin can also achieve a similar effect, although not as well as glycine (Stanley, 1981; Kilara, 1985); 4) Gly-Gly residues added to the Cterminal or N-terminal positions of bitter peptides (Shinoda et al, 1987); 5) cyclodextrin, because of its capacity for wrapping the hydrophobic functions of bitter amino acids. However, a large excess of $\alpha$-cyclodextrin solution $\left(150 \mathrm{~g} . \mathrm{l}^{-1}\right.$ ) is necessary to substantially mask the bitterness of synthesised peptides (Tamura et al, 1990). Addition of $10 \% \beta$-cyclodextrin is also effective in masking bitterness of skim milk hydrolysates (Helbig et al, 1980). However, further experiments are needed to establish its safety as a food additive. Until 1981 , Japan was the only country where the use of cyclodextrin in food products was not limited (Szejtli, 1981). Monomeric and polymeric $\beta$-cyclodextrin are commercially available; however, among polymers from $\alpha$-, $\beta$ - and $\gamma$-cyclodextrins, $\beta$ - seems to be the best in studies involving debittering of grapefruit juices (Shaw and Wilson, 1985; Shaw and Buslig, 1986); 6) starch: this sugar polymer is expected to cover the bitter compounds with "its net structure" and to prevent them from reaching the bitter taste receptor sites. However, for this purpose it is necessary to heat the mixtures of starch and bitter peptides at $100^{\circ} \mathrm{C}$ overnight (Tamura et al, 1990); 7) proteins and peptides. Due to their affinity, addition of peptide compounds such as skim milk, soybean, casein, whey protein concentrate and casein hydrolysate to bitter amino acids and peptides is effective in decreasing or masking their bitterness ( $\mathrm{Ta}$ mura et al, 1990); 8) acidic amino acids. Bitterness can be masked by aspartic acid or glutamic acid but, on the negative side, they produce sourness (Noguchi et al, 1975). However, an acidic solution of taurine reduces amino acid bitterness as effectively as other acidic amino acids and that, without sourness. Bitterness of peptides is masked only when a large excess of amino acids is added (Tamura et al, 1990).

Casein digests obtained with the ficin/ pepsin system have a very bitter flavour. Addition of pig's kidney homogenate as a source of exopeptidases (which remove amino acids singly from the ends of the peptide molecules) to the enzyme system raises the degree of hydrolysis, and yields casein digests relatively free of bitterness, containing small peptides and over $50 \%$ free amino acids (Clegg, 1973). Clegg and Mc Millan (1974) thus concluded that within the spectrum of the proteolytic enzymes in pig's kidney there is a system capable of hydrolysing the peptide responsible for the bitter flavour. It was even possible to modify this last method for the production of kilogram quantities of the relatively non-bitter casein hydrolysate for use in medical trials (Clegg et al, 1974b). Although Japanese 
workers have been more concerned about bitterness in soybean than in milk products, it is possible to extrapolate their results to milk proteins. Thus bitterness appearing during an enzymic proteolysis was found to be caused by bitter peptides bearing hydrophobic amino acid residues (especially leucine) in the C-terminal structures, and to be lessened by decomposing these $C$-terminal structures with exopeptidases such as bovine pancreas carboxypeptidase A, Aspergillus acid carboxypeptidase and leucine aminopeptidase (Fujimaki et al, 1968; Yamashita et al, 1969; Arai et al, 1970a, b). However, according to Fujimaki et al (1970b), debittering methods using these exopeptidases encounter certain limitation, since such enzymes produce significant amounts of free amino acids, mainly hydrophobic, that may affect the food quality of the proteolysates (eg if the exopeptidases are not effective in removing the odours (Arai et al, 1970b)).

Bitterness due to peptides has also been shown to be reduced by applying the plastein reaction (Fujimaki et al, 1970c). Incubation, under appropriate conditions, of a partially hydrolysed protein such as casein with a certain proteolytic enzyme gives rise to the formation of a "plastein", a high-molecular protein-like substance whose properties are quite different from those of the original protein (Nakai and LiChan, 1988). This plastein reaction has been shown by Fujimaki et al (1970b) to be very effective in obtaining non-bitter, bland proteinaceous food materials. Being highly plastein-productive enzymes (nearly equivalent to $\alpha$-chymotrypsin) Bioprase and Prozyme would be effective in debittering protein hydrolysates.

A reduction in the average hydrophobicity of peptides from casein digests treated with wheat carboxypeptidase has been observed by Umetsu et al (1983) and by Umetsu and Ichishima (1988). By releasing hydrophobic amino acids with a $\Delta f$ val- ue $>1600 \mathrm{cal}^{\mathrm{mol}-1}$ from the carboxyl termini of bitter peptides, wheat carboxypeptidase might thus be used to eliminate bitter taste in hydrolysates.

Research has been conducted by Minagawa et al (1988) into the specificity of a thermostable and metal-dependent aminopeptidase $T$ from Thermus aquaticus $\mathrm{YT}-1$. They found this enzyme to possess a broad substrate specificity, and to satisfactorily hydrolyse dipeptides and oligopeptides containing such hydrophobic amino acids as leucine, phenylalanine, and tyrosine at their $\mathrm{N}$-terminals. It also hydrolyses peptides with $\mathrm{N}$-terminal proline, but not dipeptides or tripeptides of the type containing a proline residue at a position second from the $\mathrm{N}$-terminal. Later on, the same team of scientists (Minagawa et al, 1989) proved that aminopeptidase $T$ was able to decrease and/or remove the bitterness of the peptide fractions present in casein hydrolysates obtained with 3 proteases (subtilisin, papain and trypsin). They could then assume that the bitterness formed during cheese ripening might be decreased by the action of aminopeptidase $T$, which would then contribute to shortening the ripening period of cheese by accelerating the hydrolysis of its constituent proteins and also to improving the cheese taste flavour.

Many attempts have been made to reduce bitterness in cheese manufacture. However, they have to be suited to the cheese type. Thus: 1) incubation of surface moulded soft cheeses (Camembert type) between the 3rd and 10th day following cheese-making in a slightly ammoniacal atmosphere has led to a faster increase of the $\mathrm{pH}$ in the outer layer. The growth of Penicillium caseicolum was then less rapid, proteolysis less intense and bitterness decreased (Vassal and Gripon, $1984)$; 2) bitterness of semi-liquid slurries of Cheddar cheese curd induced by a neutral microbial proteinase from Bacillus subtilis has disappeared with the addition of 
an intracellular peptidase extract from Lactococcus lactis subsp lactis (NCDO 712; "Accelase") (Cliffe and Law, 1990); 3) addition of heat-treated culture of Lactobacillus helveticus enhanced the peptidolytic activity of a Swiss round-eyed semi-hard low-fat cheese and thus reduced bitterness (Ardö et al, 1989). The same effect has been observed by Bartels et al (1987a) for a Gouda cheese to which viable cells of Lactobacillus helveticus CNRZ 32 were added; 4) the lactic acid bacterium Lactococcus lactis subsp cremoris is known to possess a debittering activity. A study conducted by Piët et al (1990) has led them to conclude that the composition of the fermentation medium influences neither the debittering activity of this bacterial strain nor the level of proteolytic activity of the cell-free extracts.

\section{Removal of bitterness}

Techniques for the removal of bitterness include adsorption on food grade resins or activated carbon, chromatographic procedures (Helbig et al, 1980), solvent extraction (eg, butanol; Matoba et al, 1970) or bioconversion to compounds which may be nonbitter or of diminished bitterness. However, removal is the choice of last resort after dilution or masking because of the added expense. Moreover, it is considerably more difficult to remove bitter compounds from solid foods because most procedures involve some form of liquidsolid extraction. Therefore, because of economic constraints or toxicological considerations, commercial methods for removal of bitter peptides are not available (Kilara, 1985).

\section{Modification or arrangement of structure}

By blocking the amino group of bitter amino acids such as leucine, valine and phen- ylalanine, and peptides by the introduction of acetyl, aspartyl and glutamyl residues, Tamura et al (1990) have proved that the simplest way to remove the bitterness is to change the structure of these compounds. Incubation of protein hydrolysates with a neutral bacterial protease in the presence of added non-bitter amino acids such as alanine, glycine, serine and glutamic and aspartic acids makes these amino acids result, via transamination, in peptides of reduced bitterness (Rouseff, 1990).

\section{Chromatographic procedures}

Supporting the hypothesis that hydrophobic compounds are mainly responsible for the bitter taste of protein hydrolysates, hydrophobic interaction chromatography (HIC) on hexylsepharose gel can be used for debittering casein digests (Lalasidis and Sjöberg, 1978). However, the limited capacity of hexylsepharose gel to bind the bitter compounds indicates a need to develop other hydrophobic gel types with improved capacity and properties.

Hydrophobic affinity chromatography with butylepoxy and alkylamino Sepharose gels is less effective in debittering casein hydrolysates than when hexylepoxy and octylepoxy Sepharose gels are used (Helbig et al, 1980). Sephadex G-10 and G-25 gels, and hydrophobic adsorbents such as Sephadex LH-20 and phenoxyacetyl cellulose are also effective in respectively reducing some bitterness from casein hydrolysates, and up to $50 \%$ from skim milk hydrolysates (Helbig et al, 1980). Roland et al (1978) have developed a hydrophobic chromatography process for debittering casein hydrolysates. For this purpose they used a phenol-formaldehyde resin polymer (Duolite S-761) which interacts preferentially with the nonpolar side chains of the aromatic and heterocyclic amino acids present in the peptides. Although having 
some limitations concerning the high proportion of talc relative to casein the low flow rate and temperature conditions, adsorption chromatography on talc (Chersi and Zito, 1976) has also been suggested for debittering casein hydrolysates (Kilara, 1985).

\section{Solvent extraction}

Some methods listed in the literature involve extraction of enzymic hydrolysates with different solvents (azeotropic secondary butyl alcohol, aqueous ethanol and aqueous isopropanol) to remove or reduce their bitter taste.

\section{Azeotropic secondary butyl alcohol (SBA)}

When a protein hydrolysate is extracted with SBA the result is a selective transfer of hydrophobic peptides and amino acids to the SBA-phase, while more hydrophilic peptides and amino acids remain in the aqueous phase. Since peptides containing these hydrophobic amino acids have a bitter taste, it is reasonable to assume that the reduction of bitterness is mainly or wholly due to removal of these compounds. Indeed, the material recovered from the SBA-phase, following the extraction of casein and whey hydrolysates, has been found to have an exceptionally strong bitter taste (Lalasidis, 1978).

\section{Aqueous ethanol (AE) and aqueous isopropanol (Al)}

Extraction of protein hydrolysates with different concentrations of ethanol or isopropanol has been effective in removing bitter compounds. Results have shown the amount of protein hydrolysates dissolved in the AE- or Al-phase to increase with the concentration of water in the mixture, while there was a gradual reduction of the con- tent of essential amino acids in the alcohol insoluble fraction. The bitter material was concentrated in the AE- or Al-phase, which had a strong bitter taste (Lalasidis, 1978). Removal of bitter peptides from enzymic fish protein hydrolysates has also been done with AE by Chakrabarti (1983). In addition, he suggested using this method to remove bitter fractions from concentrated filtrates of protein hydrolysates (eg casein) prior to vacuum drying, thus eliminating the cost of initial vacuum drying, and also minimising handling cost.

\section{Other methods}

Glass materials such as soft glass fiber, flint glass powder, and microfiber paper have been shown to have some adsorption capacity for bitter peptides from skim milk hydrolysates, while adsorption is negligible on plastic such as low density polyethylene and polyvinylidene chloride (Helbig et al, 1980).

Activated carbon treatment, previously shown to reduce the bitterness of a commercial casein hydrolysate (Murray and Baker, 1952), has also been suggested as a promising technique for improving the palatability of casein and skim milk hydrolysates (Helbig et al, 1980). Digests produced in the latter study were found suitable for use in beverage fortification. Addition of activated carbon at a level of $0.5 \mathrm{~g} / \mathrm{g}$ of protein hydrolysate made Cogan et al (1981) successful in debittering casein hydrolysate. However, they also noticed a loss of $26 \pm 2 \%$ of protein nitrogen, which was mostly due to the selective adsorption by the activated carbon of tryptophan and phenylalanine, or peptides containing them. Since this last treatment is commonly used in protein hydrolysate manufacture as a means of decolorisation, it could also accomplish debittering (Olsen and AdlerNissen, 1979). 


\section{Avoidance or prevention of bitterness}

Since the proteolytic cleavage of milk proteins often results in the formation of bitter tasting peptides after extensive hydrolysis, control and termination of the hydrolytic reaction at a desirable degree of hydrolysis is crucial to avoid or prevent the formation of bitter peptides (Vegarud and Langsrud, 1989).

Bitterness can be prevented by chemical modification of functional side-chains in amino acids of proteases such as subtilisins, chymotrypsin or trypsin. Thus, nitration, iodination, glutarylation, succinylation or modification of carboxyl groups lead to changes in the enzymic properties with regard to the hydrolysis of polypeptide substrates. However, the concerted effort of kinetic, crystallographic, and chemical studies is still necessary for a more complete picture of the interactions of proteolytic enzymes with their natural substrates, the proteins (eg caseins), to obtain more valuable information both about the size and the specificity of the active sites. Proteases compatible with the substrates could thus be used. Choosing alcalase, a protease known to cleave proteins at the carboxylic side of hydrophobic amino acids, would result in less bitterness than if the cleavage were carried out by a protease cleaving at hydrophilic amino acids (Svendsen, 1976). Thus, according to Pélissier and Manchon (1976), Adler-Nissen (1986c) has elaborated on the influence of the protease used for the production of enzymic hydrolysates on the development of bitterness. He thus concluded that theoretically hydrophobic proteases (eg alcalase) will produce peptides with an average hydrophobicity which will decrease with an increment of the peptide chain length. Non-hydrophobic proteases (eg trypsin), on the contrary, will produce peptides with a relative excess of hydrophobic amino ac- ids in endopositions and with an average hydrophobicity increasing with peptide chain length. In reality, however, predictions about the bitterness of peptides cannot be made with regard to the effect of protease specificity. This arises especially for the long peptides, which may form loops and clusters and thereby reduce their bitterness, and also if a separation is carried out at the isoelectric point.

\section{CONCLUSION}

Bitterness, which can be a problem in just about all foods -fruits, vegetables, protein products, processed and fermented products- is reasonably well correlated with the degree of molecule hydrophobicity. The sensation of bitterness requires the simultaneous participation of a number of different papillae. In order for the compound to produce a response detectable as bitterness, the conformation of this compound must be sufficiently specific and have sufficient binding energy to distort the microstructural conformation of the receptor membrane.

This review article has been mainly concerned with this sensory defect in cheese (formation, isolation, identification, structure, masking or inhibition). Based on the different hypotheses found in literature and on the work carried out in our laboratory, we propose a new model for the development of bitter peptides in Cheddar cheese (fig 13). This model is mainly concerned with the development of the Cheddar flavour and the elimination of bitter peptides in Cheddar cheese. In a first step, long chain non-bitter peptides are obtained from the action of rennet and non-starter Lactobacillus. Starter enzymes are presumed to further attack these long chain non-bitter peptides and release bitter polypeptides. Addition of debittering lactic bacteria dur- 


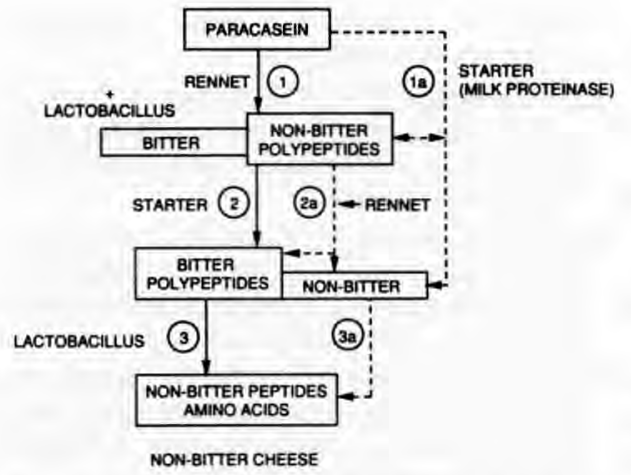

Fig 13. Proposed model for the production of non-bitter Cheddar cheese.

Modèle proposé pour la fabrication de fromage Cheddar non-amer.

ing cheese manufacture has an important effect. Indeed, being rich in aminopeptidases and dipeptidases, dipeptidyl peptidase and carboxipeptidase (only for Lactobacillus casei), these bacteria, especially Lactobacillus, are then able to hydrolyse bitter peptides and produce a Cheddar cheese devoid of bitter off-flavour. More studies will be necessary to determine whether it is appropriate for Cheddar cheese manufactured with pasteurised milk and under conditions of accelerated ripening.

As new analytical techniques and equipment are developed, information about the identity of the bitter principle and the mechanism of its formation is being accumulated and will help to clarify many unresolved issues of importance to the scientist. Thus, recent techniques of high-performance liquid chromatography coupled to fast atom bombardment-mass spectrometry will allow isolation, molecular weight and sequence determination of peptides from milk products (Lemieux and Amiot, 1991). Important properties for making peptides extremely bitter are high hydrophobicity, basic amino acids in the amino end and presence of proline; moreover, intermedi- ate-sized peptides could be expected to be more bitter than the smaller one. Although procedures developed to remove or reduce bitterness in food products such as soy can be applied or adapted to milk products, many of them are still not practicable or economical for commercial use, or involve compounds which have not been approved for food use. The most effective methods for bitterness control in cheese involve reduction of total proteolytic activity by culture selection, use of mixed cultures, proper selection and use of coagulant, and adjusting environmental factors (ie temperature, $\mathrm{pH}$, etc). Thus it is now possible to manufacture non-bitter cheese with accelerated ripening and produce dietetic enzymic casein hydrolysates with reduced bitterness.

\section{REFERENCES}

Abu-Tarboush HM, Marshall RT, Heymann $H$ (1989) Peptides produced by selected lactose-positive and lactose-negative lactococci in a model cheese ripening system. J Dairy Sci 72, 3143-3148

Adda J, Gripon JC, Vassal L (1982) The chemistry of flavour and texture generation in cheese. Food Chem 9, 115-129

Adler-Nissen J (1976) Enzymatic hydrolysis of proteins for increased solubility. J Agric Food Chem 24, 1090-1093

Adler-Nissen J (1984) Control of the proteolytic reaction and of the level of bitterness in protein hydrolysis processes. J Chem Technol Biotechnol 34B, 215-222

Adler-Nissen J (1986a) Relationship of structure to taste of peptides and peptide mixtures. In: Protein Tailoring for Food and Medical Uses (Feeney RE, Whitaker JR, eds) Marcel Dekker Inc, New York

Adler-Nissen $\mathrm{J}$ (1986b) A review of food protein hydrolysis - specific areas. In: Enzymic $\mathrm{Hy}$ drolysis of Food Proteins. Elsevier Appl Sci Publ, New York

Adler-Nissen J (1986c) ISSPH - The production and properties of an enzymic food protein hydrolysate. In: Enzymic Hydrolysis of Food Proteins. Elsevier Appl Sci Publ, New York 
Aoyagi $H$, Izumiya $N(1977)$ Synthesis of $\alpha$ substance-lb in Saccharomyces cerevisiae. Bull Chem Soc Jpn 50, 2387-2390

Arai $S$, Yamashita $M$, Kato $H$, Fujimaki $M$ (1970a) Applying proteolytic enzymes on soybean. Part V. A nondialyzable bitter peptide in peptic hydrolyzate of soybean protein and its bitterness in relation to the chemical structure. Agric Biol Chem 34, 729-738

Arai S, Noguchi M, Kurosawa S, Kato H, Fujimaki M (1970b) Applying proteolytic enzymes on soybean. 6 . Deodorization effect of aspergillopeptidase $A$ and debittering effect of Aspergillus acid carboxypeptidase. J Food Sci 35, 392-395

Ardö Y, Larsson PO, Lindmark Mansson $\mathrm{H}, \mathrm{He}$ denberg A (1989) Studies of peptidolysis during early maturation and its influence on low-fat cheese quality. Milchwissenschaft 44, 485-490

Bartels HJ, Johnson ME, Olson NF (1987a) Accelerated ripening of Gouda cheese. I. Effect of heat-shocked thermophilic lactobacilli and streptococci on proteolysis and flavor development. Michwissenschaft 42, 83-88

Bartels HJ, Johnson ME, Olson NF (1987b) Accelerated ripening of Gouda cheese. 2 . Effect of freeze-shocked Lactobacillus helveticus on proteolysis and flavor development. Milchwissenschaft 42, 139-144

Belitz HD, Sparrer D (1971) Isolierung eines bitteren Peptids aus einem chymotryptischen Caseinhydrolysat. Lebensm Wiss Technol 4, 131-132

Belitz HD, Wieser H (1985) Bitter compounds: occurrence and structure-activity relationships. Food Rev Int 1, 271-354

Belitz HD, Chen W, Jugel H, Treleano R, Wieser H, Gasteiger J, Marsili M (1979) Sweet and bitter compounds: structure and taste relationships. In: Food Taste Chemistry (Boudreau JC, ed), Am Chem Soc (ACS) Symp Ser 115, Washington

Belitz HD, Chen W, Jugel H, Stempfl H, Treleano R, Wieser $H$ (1983) Quantitative structure activity relationship (QSAR) in taste and olfaction of bitter tasting compounds. Chem Ind 23-26

Biede SL, Hammond EG (1979) Swiss cheese flavor: II. Organoleptic analysis. J Dairy Sci $62,238-248$

Birch GG, Lee CK (1976) Structural functions and taste in the sugar series: the structural basis of bitterness in sugar analogues. J Food Sci 41, 1403-1407

Bull $\mathrm{HB}$, Breese K (1974) Surface tension of amino acid solutions: a hydrophobicity scale of the amino acid residues. Arch Biochem Biophys $161,665-670$

Carr JW, Loughheed TC, Baker BE (1956) Studies on protein hydrolysis. IV. Further observations on the taste of enzymic protein hydrolysates. J Sci Food Agric 7, 629-637

Castberg HB, Morris HA (1976) Degradation of milk proteins by enzymes from lactic acid bacteria used in cheese making. A review. Milchwissenschaft $31,85-90$

Chakrabarti R (1983) A method of debittering fish protein hydrolysate. J Food Sci Technol 20, 154-156

Champion HM, Stanley DW (1982) HPLC separation of bitter peptides from Cheddar cheese. Can Inst Food Sci Technol J 15, 283-288

Chersi A, Zito R (1976) Isolation of tryptophancontaining peptides by adsorption chromatography. Anal Chem 73, 471-476

Clegg KM (1973) Improvements in or relating to the production of pre-digested forms of protein. Br Patent 1338936

Clegg KM, Mc Millan AD (1974) Dietary enzymic hydrolysates of protein with reduced bitterness. J Food Technol 9, 21-29

Clegg KM, Lim CL, Manson W (1974a) The structure of a bitter peptide derived from casein by digestion with papain. $J$ Dairy Res $41,283-287$

Clegg KM, Smith G, Walker AL (1974b) Production of an enzymic hydrolysate of casein on a kilogram scale. J Food Technol 9, 425-431

Cliffe AJ, Law BA (1990) Peptide composition of enzyme-treated Cheddar cheese slurries, determined by reverse phase high performance liquid chromatography. Food Chem 36, 73-80

Cliffe AJ, Revell D, Law BA (1989) A method for the reverse phase high performance liquid chromatography of peptides from Cheddar cheese. Food Chem 34, 147-160

Cogan U, Moshe M, Mokady S (1981) Debittering and nutritional upgrading of enzymic casein hydrolysates. J Sci Food Agric 32, 459-466

Creamer LK (1979) Chemical aspects of food quality. In: Developments in Food Science. 2. Proc 5th Int Congr Food Sci Technol, Kyoto, 
Japan 1978 (Chiba H, Fujimaki M, Iwai K, Mitsuda $\mathrm{H}$, Morita $Y$, eds) Elsevier, Amsterdam

Czulak J (1959) Bitter flavour in cheese. Aust $J$ Dairy Technol 14, 177-179

Czulak J, Shimmin PD (1961) Further notes on bitter flavour in cheese. Aust $J$ Dairy Technol 16, 96-98

Desmazeaud MJ, Hermier JH (1972) Isolement et détermination de la composition qualitative de peptides issus de la caséine, stimulant la croissance de Streptococcus thermophilus. Eur J Biochem 28, 190-198

Desmazeaud MJ, Gripon JC (1977) General mechanism of protein breakdown during cheese ripening. Milchwissenschaft 32, 731734

Dinesen N (1974) The real value of cheese coagulants. Dairy Ice Cream Field 157, 78-80

Dulley JR, Kitchen BJ (1972) Phosphopeptides and bitter peptides produced by rennet. Aust J Dairy Technol 27, 10-11

Dunhill $P$ (1965) How proteins acquire their structure. Sci Progr 53, 609

Edwards JL Jr, Kosikowski FV (1983) Bitter compounds from Cheddar cheese. $J$ Dairy Sci $66,727-734$

Emmons DB, McGugan WA, Elliott JA (1960a) Effect of strain starter culture and manufacturing procedure on bitterness in Cheddar cheese. J Dairy Sci 43, 861-862

Emmons DB, McGugan WA, Elliott JA (1960b) Nitrogen distribution in Cheddar cheese as related to bitterness and strain of starter culture. J Dairy Sci 43,862

Emmons DB, McGugan WA, Elliott JA, Morse PM (1962a) Effect of strain of starter culture and of manufacturing procedure on bitterness and protein breakdown in Cheddar cheese. J Dairy Sci 45, 332-342

Emmons DB, McGugan WA, Elliott JA, Morse PM (1962b) Effect of combining single-strain cultures as cheese starter on bitterness in Cheddar cheese at six months of age. $J$ Dairy Sci 45, 595-600

Exterkate FA (1976) Comparison of strains of Streptococcus cremoris for proteolytic activities associated with the cell wall. Neth Milk Dairy J 30, 95-105

Exterkate FA, Stadhouders J (1971) Pyrrolidone carboxylyl peptidase activity in bitter and non-bitter strains of Streptococcus cremoris. Neth Milk Dairy J 25, 240-245

Fox PF, Walley BF (1971) Influence of sodium chloride on the proteolysis of casein by rennet and by pepsin. J Dairy Res 38, 165-170

Fujimaki M, Yamashita M, Okazawa $Y$, Arai S (1968) Diffusable bitter peptides in peptic hydrolyzate of soybean protein. Agric Biol Chem 32, 794-795

Fujimaki M, Yamashita M, Okazawa $Y$, Arai S (1970a) Applying proteolytic enzymes on soybean. 3. Diffusable bitter peptides and free amino acids in peptic hydrolyzate of soybean protein. J Food Sci 35, 215-218

Fujimaki M, Yamashita M, Arai $S$, Kato $H$ (1970b) Plastein reaction - its application to debittering of proteolyzates. Agric Biol Chem $34,483-484$

Fujimaki M, Yamashita M, Arai $S$, Kato $H$ (1970c) Enzymatic modification of proteins in foodstuffs. Part I. Enzymatic proteolysis and plastein synthesis application for preparing bland protein-like substances. Agric Biol Chem 34, 1325-1332

Fukui $H$, Kanehisa $H$, Ishibashi $N$, Miyake I, Okai H (1983) Studies of bitter peptides from casein hydrolyzate. I. Synthesis of bitter peptide BPla corresponding to Arg-Gly-Pro-ProPhe-lle-Val from casein hydrolyzate by alkaline proteinase of Bacillus subtilis. Bull Chem Soc Jpn 56, 766-769

Furtado MM (1984) Prevention of bitter taste in cheeses. Int Dairy Fed Bull 177, 113-122

Gardner RJ (1978) Lipophilicity and bitter taste. J Pharm Pharmacol 30, 531-532

Gardner RJ (1980) Correlation of bitterness thresholds of amino acids and peptides with molecular connectivity. J Sci Food Agric 31, 23-30

Gatfield IL (1981) Isolation and properties of bitter-sensitive proteins via affinity chromatography. In: Flavour'81. Proc 3rd Int Weurman Symp (Schreier P, ed) Walter de Gruyter, Berlin

Gordon DF Jr, Speck ML (1965a) Bitterness in milk cultures of Streptococcus cremoris. $J$ Dairy Sci 48, 499-500

Gordon DF Jr, Speck ML (1965b) Bitter peptide isolated from milk cultures of Streptococcus cremoris. Appl Microbiol 13, 537-542 
Gordon WG, Groves ML (1975) Primary sequence of beta, gamma, and minor caseins. J Dairy Sci 58, 574-582

Green ML, Foster PMD (1974) Comparison of the rates of proteolysis during ripening of Cheddar cheeses made with calf rennet and swine pepsin as coagulants. J Dairy Res 41 , 269-282

Gripon JC, Desmazeaud MJ, Le Bars D, Bergère JL (1975) Étude du rôle des microorganismes et des enzymes au cours de la maturation des fromages. II. Influence de la présure commerciale. Lait 55, 502-516

Guigoz Y, Solms J (1974) Isolation of a bitter tasting peptide from "Alpkäse", a Swiss mountain-cheese. Lebensm Wiss Technol 7, 356-357

Guigoz Y, Solms J (1976) Bitter peptides, occurrence and structure. Chem Senses Flavor 2 , 71-84

Hamilton JS, Hill RD, van Leeuwen H (1974) A bitter peptide from Cheddar cheese. Agric Biol Chem 38, 375-379

Harwalkar VR (1967) Comparative study of bitter flavor fraction obtained from nonbitter and bitter Cheddar cheese. J Dairy Sci 50, 956

Harwalkar VR, Elliott JA (1965) Isolation and partial purification of bitter components from Cheddar cheese. J Dairy Sci 48, 784

Harwalkar VR, Elliott JA (1971) Isolation of bitter and astringent fractions from Cheddar cheese. J Dainy Sci 54, 8-11

Harwalkar VR, Seitz EW (1971) Production of bitter flavor components by lactic cultures. J Dairy Sci 54, 12-14

Hashimoto A, Aoyagi H, Izumiya N (1980) Synthetic identification of bitter heptapeptide in tryptic hydrolysate of casein. Bull Chem Soc Jpn 53, 2926-2928

Helbig NB, Ho L, Christy GE, Nakai S (1980) Debittering of skim milk hydrolysates by adsorption for incorporation into acidic beverages. J Food Sci 45, 331-335

Hettinga $H$, Parmelee CE (1965) Amino acid analyses of fractions from bitter and nonbitter Gouda cheese. J Dairy Sci 48, 784

Hill RD, van Leeuwen H (1974) Bitter peptides from hydrolysed casein coprecipitate. Aust $J$ Dairy Technol 29, 32-34

Hodges R, Kent SBH, Richardson BC (1972) The mass spectra of some permethylated ac- etylpeptides. Biochim Biophys Acta 257, 5460

Huber L, Klostermeyer H (1974) Isolation of a bitter peptide from the cheese "Butterkäse" and its identification. Milchwissenschaft 29, 449-455

liyama S, Toko K, Yamafuji K (1986) Effect of bitter substances on a model membrane system of taste reception. Agric Biol Chem 50, 2709-2714

Ikeda $\mathrm{K}$ (1909) On a new seasoning. $J$ Tokyo Chem Soc 30, 820-836

Ishibashi N, Arita $\mathrm{Y}$, Kanehisa $\mathrm{H}$, Kouge $\mathrm{K}$, Okai H, Fukui S (1987a) Bitterness of leucinecontaining peptides (studies on flavored peptides. Part I). Agric Biol Chem 51, 2389-2394

Ishibashi N, Sadamori K, Yamamoto O, Kanehisa $H$, Kouge $K$, Kikuchi E, Okai H, Fukui S (1987b) Bitterness of phenylalanine- and tyrosine-containing peptides (studies on flavored peptides. Part II). Agric Biol Chem 51, 3309-3313

Ishibashi N, Ono I, Kato K, Shigenaga $T$, Shinoda I, Okai H, Fukui S (1988a) Role of the hydrophobic amino acid residue in the bitterness of peptides. Agric Biol Chem 52, 91-94

Ishibashi N, Kubo T, Chino M, Fukui H, Shinoda I, Kikuchi E, Okai H, Fukui S (1988b) Taste of proline-containing peptides (studies on flavored peptides. Part IV). Agric Biol Chem 52, 95-98

Ishibashi N, Kouge K, Shinoda I, Kanehisa H, Okai H (1988c) A mechanism for bitter taste sensibility in peptides. Agric Biol Chem 52, 819-827

Jago GR (1962) Proteolysis of milk proteins in relation to bitter flavour in cheese. Aust $J$ Dairy Technol 17, 83-85

Jago GR (1974) Control of the bitter flavour defect in cheese. Aust J Dairy Technol 29, 9496

Kaminogawa S, Yan TR, Azuma N, Yamauchi K (1986) Identification of low molecular weight peptides in Gouda-type cheese and evidence for the formation of these peptides from 23 $\mathrm{N}$-terminal residues of $\alpha_{51}$-casein by proteinases of Streptococcus cremoris H61. J Food Sci 51, 1253-1256, 1264

Kanehisa H (1984) Studies of bitter peptides from casein hydrolyzate. VI. Syntheses and bitter taste of BPIc (Val-Tyr-Pro-Phe-Pro-Pro- 
Gly-lle-Asn-His) and its analogs and fragments. Bull Chem Soc Jpn 57, 97-102

Kanehisa H, Okai $H$ (1984) Studies of bitter peptides from casein hydrolyzate. $V$. Bitterness of the synthetic $\mathrm{N}$-terminal analogs of desGly-BPla (Arg-Pro-Pro-Phe-lle-Val). Bull Chem Soc Jpn 57, 301-302

Kanehisa $H$, Miyake I, Okai $H$, Aoyagi $H$, IzUmiya N (1984) Studies of bitter peptides from casein hydrolyzate. $X$. Synthesis and bitter taste of H-Arg-Gly-Pro-Phe-Pro-lle-Ile-Val$\mathrm{OH}$ corresponding to $\mathrm{C}$-terminal portion of $\beta$ casein. Bull Chem Soc Jpn 57, 819-822

Kelly CD (1932) Influence of certain lactic acid streptococci on the chemical changes in Cheddar cheese during ripening. NY Agric Expt Sta Tech Bull 200, 3-28

Kilara A (1985) Enzyme-modified protein food ingredients. Process Biochem 20, 149-157

Kirimura J, Shimizu A, Kimizuka A, Ninomiya T, Katsuya N (1969) The contribution of peptides and amino acids to the taste of foodstuffs. J Agric Food Chem 17, 689-695

Klimovsky I, Zvyagintsev V, Gudkov A, Medvedeva Z (1970) Detection of "bitter" strains of lactic acid streptococci. In: XVIII Int Dairy Congr $1 \mathrm{E}, 119$

Kubota T, Kubo I (1969) Bitterness and chemical structure. Nature (Lond) 223, 97-99

Kuchroo CN, Fox PF (1983) Fractionation of the water soluble nitrogen from Cheddar cheese: chromatographic methods. Milchwissenschaft 38, 76-79

Lalasidis G (1978) Four new methods of debittering protein hydrolysates and a fraction of hydrolysates with high content of essential amino acids. Ann Nutr Aliment 32, 709-723

Lalasidis G, Sjöberg LB (1978) Two new methods of debittering protein hydrolysates and a fraction of hydrolysates with exceptionally high content of essential amino acids. J Agric Food Chem 26, 742-749

Law BA (1987) Proteolysis in relation to normal and accelerated cheese ripening. In: Cheese: Chemistry, Physics and Microbiology, Vol 1: General Aspects (Fox PF, ed) Elsevier Appl Sci Publ, London

Lawrence RC, Gilles J (1969) The formation of bitterness in cheese: a critical evaluation. $N Z$ J Dairy Technol 4, 189-196

Lawrence RC, Creamer LK, Gilles J, Martley FG (1972) Cheddar cheese flavour. I. The role of starters and rennets. NZ J Dairy Technol 7, 32-37

Lemieux L, Amiot J (1990) High-performance liquid chromatography of casein hydrolysates phosphorylated and dephosphorylated. I. Peptide mapping. J Chromatogr 519, 299321

Lemieux L, Amiot J (1991) Study of the efficiency of a mobile phase used in size-exclusion HPLC for the separation of peptides from a casein hydrolysate phosphorylated according to their hydrodynamic volume. Chromatographia 32,

Lemieux L, Simard RE (1991) Bitter flavour in dairy products. I. A review of the factors likely to influence its development, mainly in cheese manufacture. Lait 71, 599-636

Lemieux L, Puchades R, Simard RE (1989) Size-exclusion HPLC separation of bitter and astringent fractions from Cheddar cheese made with added Lactobacillus strains to accelerate ripening. J Food Sci 54 , 1234-1237

Lowrie RJ (1977) Influence of lactic streptococci on bitter flavor development in cheese. J Dairy Sci 60, 810-814

Lowrie RJ, Lawrence RC (1972) Cheddar cheese flavour. IV. A new hypothesis to account for the development of bitterness. NZJ Dairy Technol 7, 51-53

Lowrie RJ, Lawrence RC, Pearce LE, Richards EL (1972) Cheddar cheese flavour. III. The growth of lactic streptococci during cheesemaking and the effect on bitterness development. NZJ Dairy Technol 7, 44-50

Mabbitt LA, Chapman HR, Berridge NJ (1955) Experiments in cheesemaking without starter. J Dairy Res 22, 365-373

Manning DJ, Nursten HE (1985) Flavour of milk and milk products. In: Developments in Dairy Chemistry 3 (Fox PF, ed) Elsevier Appl Sci Publ, London

Martley FG (1975a) The behaviour and role of starter streptococci in Camembert cheesemaking. NZJ Dairy Technol 10, 12-17

Martley FG (1975b) Comportement et rôle des streptocoques lactiques du levain en fabrication de Camembert. Lait 55, 310-323

Martley FG, Lawrence RC (1972) Cheddar cheese flavour. II. Characteristics of single strain starters associated with good or poor 
flavour development. NZJ Dairy Technol 7, 38-44

Matoba T, Hata T (1972) Relationship between bitterness of peptides and their chemical structures. Agric Biol Chem 36, 1423-1431

Matoba T, Nagayasu C, Hayashi R, Hata T (1969) Bitter peptides in tryptic hydrolysate of casein. Agric Biol Chem 33, 1662-1663

Matoba T, Hayashi R, Hata T (1970) Isolation of bitter peptides from tryptic hydrolysate of casein and their chemical structure. Agric Biol Chem 34, 1235-1243

McKellar RC (1981) Development of off-flavors in ultra-high temperature and pasteurized milk as a function of proteolysis. J Dairy Sci $64,2138-2145$

McKellar RC, Froehlich DA, Butler G, Cholette H, Campbell C (1984) The effect of uncooled storage on proteolysis bitterness and apparent viscosity in ultra-high temperature milk. Can Inst Food Sci Technol J 17, 14-17

Mercier JC, Grosclaude F, Ribadeau-Dumas B (1971) Structure primaire de la caséine $\alpha_{s 1}$ bovine. Séquence complète. Eur J Biochem 23, $41-51$

Mercier JC, Grosclaude F, Ribadeau-Dumas B (1972) Primary structure of bovine caseins. A review. Milchwissenschaft 27, 402-408

Minagawa $E$, Kaminogawa $S$, Matsuzawa $H$, Ohta T, Yamauchi K (1988) Isolation and characterization of a thermostable aminopeptidase (aminopeptidase T) from Thermus aquaticus $\mathrm{YT}-1$, an extremely thermophilic bacterium. Agric Biol Chem 52, 1755-1763

Minagawa E, Kaminogawa S, Tsukasaki F, Yamauchi K (1989) Debittering mechanism in bitter peptides of enzymatic hydrolysates from milk casein by aminopeptidase $T, J$ Food Sci 54, 1225-1229

Minamiura N, Matsumura $\mathrm{Y}$, Yamamoto $T$ (1972a) Bitter peptides in the casein digests with bacterial proteinase. II. A bitter peptide consisting of tryptophan and leucine. $J$ Biochem 72, 841-848

Minamiura N, Matsumura $\mathrm{Y}$, Fukumoto J, Yamamoto $T$ (1972b) Bitter peptides in cow milk casein digests with bacterial proteinase. Part 1. Isolation and determination of amino acid sequence of a bitter peptide. Agric Biol Chem 36, 588-595
Miyake I, Kouge K, Kanehisa H, Okai H (1983) Studies of bitter peptides from casein hydrolyzate. III. Bitter taste of synthetic analogs of BPla (Arg-Gly-Pro-Pro-Phe-lle-Val) containing d-proline or glycine in place of 1-proline. Bull Chem Soc Jpn 56, 1678-1681

Monnet V, Le Bars D, Gripon JC (1986) Specificity of a cell wall proteinase from Streptococcus lactis NCDO763 towards bovine $\beta$ casein. FEMS Microbiol Lett 36, 127-131

Murray TK, Baker BE (1952) Studies on protein hydrolysis. I. Preliminary observations on the taste of enzymic protein-hydrolysates. J Sci Food Agric 3, 470-475

Nagao M, Maki M, Sasaki R, Chiba H (1984) Isolation and sequence analysis of bovine $\alpha_{s 1}$-casein cDNA clone. Agric Biol Chem 48, 1663-1667

Nakai S, Li-Chan E (1988) Importance of hydrophobic interactions in modification of structure and function of food proteins. In: Hydrophobic Interactions in Food Systems. CRC Press inc, Boca Raton, FL

Ney KH (1971) Prediction of bitterness of peptides from their amino acid composition. $Z$ Lebensm Forsch 147, 64-68

Ney KH (1979) Bitterness of peptides: amino acid composition and chain length. In: Food Taste Chemistry (Boudreau JC, ed) Am Chem Soc (ACS) Symp Ser 115, Washington

Ney KH (1981) Recent advances in cheese flavor research. In: The Quality of Foods and Beverages. Chemistry and Technology. Vol 1 (Charalambous G, Inglett G, eds) Academic Press Inc, New York

Noguchi $M$, Yamashita $M$, Arai $S$, Fujimaki $M$ (1975) On the bitter-masking activity of a glutamic acid-rich oligopeptide fraction. I Food Sci 40, 367-369

Noomen A (1983) Proteolysis in cheese: sources and consequences. Neth Milk Dairy $J 37$, 96-97

Nosho Y, Otagiri K, Shinoda I, Okai H (1985) Studies on a model of bitter peptides including arginine, proline and phenylalanine residues. II. Bitterness behavior of a tetrapeptide (Arg-Pro-Phe-Phe) and its derivatives. Agric Biol Chem 49, 1829-1837

Ohyama S, Ishibashi N, Tamura M, Nishizaki H, Okai H (1988) Synthesis of bitter peptides 
composed of aspartic acid and glutamic acid. Agric Biol Chem 52, 871-872

O'Keeffe RB, Fox PF, Daly C (1975) Proteolysis in Cheddar cheese: influence of the rate of acid production during manufacture. $J$ Dairy Res 42, 111-122

Okai H (1976) Relationship between bitterness and chemical structure in synthetic peptides. Pept Chem 14, 139-142

Olsen HS, Adler-Nissen J (1979) Industrial production and application of a soluble enzymatic hydrolyzate of soya protein. Process Biochem 14, 6, 8, 10-11

Otagiri K, Miyake I, Ishibashi N, Fukui H, Kanehisa H, Okai H (1983) Studies of bitter peptides from casein hydrolyzate. II. Syntheses of bitter peptide fragments and analogs of BPla (ArgGly-Pro-Pro-Phe-lle-Val) from casein hydrolyzate. Bull Chem Soc Jpn 56, 1116-1119

Otagiri $K$, Shigenaga $T$, Kanehisa $H$, Okai $H$ (1984) Studies of bitter peptides from casein hydrolyzate. IV. Relationship between bitterness and hydrophobic amino acids moiety in the C-terminal of BPla (Arg-Gly-Pro-Pro-Phelle-Val). Bull Chem Soc Jpn 57, 90-96

Otagiri K, Nosho Y, Shinoda I, Fukui H, Okai H (1985) Studies on a model of bitter peptides including arginine, proline and phenylalanine residues. I. Bitter taste of di- and tri-peptides, and bitterness increase of the model peptides by extension of the peptide chain. Agric Biol Chem 49, 1019-1026

Pélissier JP, Manchon P (1976) Comparative study of the bitter taste of enzymic hydrolysates from cow, ewe and goat caseins. $J$ Food Sci 41, 231-233

Pélissier JP, Ribadeau-Dumas B (1976) Pourquoi les fromages ont-ils parfois un goùt amer ? Peut-on y remédier ? Rev Lait Fr 341 , $217,219,221,223$

Pélissier JP, Mercier JC, Ribadeau-Dumas B (1974) Étude de la protéolyse des caséines $\alpha_{s 1}$ et $\beta$ bovines par la présure. Ann Biol Anim Biochim Biophys 14, 343-362

Perry KD, McGillivray WA (1964) The manufacture of "normal" and "starter-free" Cheddar cheese under controlled bacteriological conditions. J Dairy Res 31, 155-165

Petritschek A, Lynen F, Belitz HD (1972) Investigations on bitter peptides. II. Appearance of bitter taste in enzymatic hydrolysates of different proteins. Lebensm Wiss Technol 5, 77-81

Pham AM, Nakai S (1984) Application of stepwise discriminant analysis to high pressure liquid chromatography profiles of water extract for judging ripening of Cheddar cheese. J Dairy Sci 67, 1390-1396

Phelan JA, Guiney J, Fox PF (1973) Proteolysis of $\beta$-casein in Cheddar cheese. J Dairy Res 40, 105-112

Piët MPJ, de Roos AL, Bommelé MWC, Oosterom E, Persoon NLM (1990) Characterization of debittering activities of Lactococcus lactis. Poster, 23rd Int Dairy Congr (FIL), Montreal, Canada

Raadsveld CW (1953) Bitter compounds from cheese. In: XIIIth Int Dairy Congr (Proc) II (Sec II), 676-680

Reid JR, Moore $\mathrm{CH}$, Midwinter GG, Pritchard GG (1991) Action of a cell wall proteinase from Lactococcus lactis subsp cremoris SK 11 on bovine $\alpha_{s 1}$-casein. Appl Microbiol Biotechnol 35, 222-227

Reiter B, Fryer TF, Pickering A, Chapman HR, Lawrence RC, Sharpe ME (1967) The effect of the microbial flora on the flavour and free fatty acid composition of Cheddar cheese. $J$ Dairy Res 34, 257-272

Reville WJ, Fox PF (1978) Soluble protein in Cheddar cheese: a comparison of analytical methods. Ir J Food Sci Technol 2, 67-76

Ribadeau-Dumas B, Brignon G, Grosclaude F, Mercier JC (1972) Structure primaire de la caséine $\beta$ bovine. Séquence complète. Eur $J$ Biochem 25, 505-514

Richardson BC, Creamer LK (1970) Proteolytic degradation of caseins in Cheddar cheese. NZJ Dairy Sci Technol 5, 166-167

Richardson BC, Creamer LK (1973) Casein proteolysis and bitter peptides in Cheddar cheese. NZJ Dairy Sci Technol 8, 46-51

Riddet W, Valentine GM, Whitehead HR (1932) A starter producing bitterness in cheese. NZJ Agric 44, 32-34

Roland JF, Mattis DL, Kiang S, Alm WL (1978) Hydrophobic chromatography: debittering protein hydrolysates. I Food Sci 43,1491 1493 
Rouseff RL (1990) Bitterness in Foods and Beverages: Developments in Food Science 25. Elsevier Sci Publ, Amsterdam

Schalinatus E, Behnke U (1975a) Studies on the bitter peptides from casein and cheese. Part II. Formation and isolation of bitter peptides. Nahrung 19, 433-445

Schalinatus E, Behnke U (1975b) Studies on the bitter peptides from casein and cheese. Part III. Characterization of bitter peptides and studies on the elimination of bitter taste. Nahrung 19, 447-459

Shaw PE, Wilson CW III (1985) Reduction of bitterness in grapefruit juice with $\beta$ cyclodextrin polymer in a continuous-flow process. J Food Sci 50, 1205-1207

Shaw PE, Buslig BS (1986) Selective removal of bitter compounds from grapefruit juice and from aqueous solution with cyclodextrin polymers and with Amberlite XAD-4. J Agric Food Chem 34, 837-840

Shiba T, Nunami KI (1974) Structure of a bitter peptide in casein hydrolyzate by bacterial proteinase. Tetrahedron Lett 509-512

Shigenaga $T$, Otagiri $K$, Kanehisa $H$, Okai $H$ (1984) Studies of bitter peptides from casein hydrolyzate. VII. Bitterness of the retro-BPla (Val-lle-Phe-Pro-Pro-Gly-Arg) and its fragments. Bull Chem Soc Jpn 57, 103-107

Shinoda I, Okai H (1985) Sweetness and bitterness contributions of structural units of aspartam and some analogues. J Agric Food Chem 33, 792-795

Shinoda I, Tada M, Otagiri K, Okai H (1985a) Bitter taste of Pro-Phe-Pro-Gly-Pro-lle-Pro corresponding to the partial sequence (positions 61-67) of bovine $\beta$-casein. In: Peptide Chemistry 1985: 23rd Symp Peptide Chemistry (Proc) Kyoto, 287-290

Shinoda I, Fushimi A, Kato $H$, Okai $H$, Fukui $S$ (1985b) Bitter taste of synthetic C-terminal tetradecapeptide of bovine $\beta$-casein. $\mathrm{H}$ Pro 196-Val-Leu-Gly-Pro-Val-Arg-Gly-Pro-PhePro-lle-lle-Val209-OH, and its related peptides. Agric Biol Chem 49, 2587-2596

Shinoda I, Tada M, Okai H, Fukui S (1986a) Bitter taste of H-Pro-Phe-Pro-Gly-Pro-lle-Pro$\mathrm{OH}$ corresponding to the partial sequence (positions 61-67) of bovine $\beta$-casein, and related peptides. (Studies of bitter peptides from casein hydrolyzate. Part XII). Agric Biol Chem 50, 1247-1254
Shinoda I, Okai H, Fukui S (1986b) Bitter taste of $\mathrm{H}$-Val-Val-Val-Pro-Pro-Phe-Leu-OH corresponding to the partial sequence (positions 82-88) of bovine $\beta$-casein, and related peptides. Agric Biol Chem 50, 1255-1260

Shinoda I, Nosho Y, Kouge K, Ishibashi N, Okai $\mathrm{H}$, Tatsumi K, Kikuchi E (1987) Variation in bitterness potency when introducing Gly-Gly residue into bitter peptides. Agric Biol Chem $51,2103-2110$

Shiraishi H, Okuda K, Sato Y, Yamaoka N, Tuzimura K (1973) Taste of proline-containing peptides. Agric Biol Chem 37, 2427-2428

Sohn KH, Lee HJ (1988) Bitter peptides derived from $\alpha_{51}$ - and $\beta$-casein digested with alkaline protease from Bacillus subtilis. Korean $J$ Food Sci Technol 20, 659-665

Solms J, Vutaz L, Egli RH (1965) The taste of Land D-amino acids. Experientia 21, 692-694

Stadhouders J (1962) The proteolytic activity of rennet and starter bacteria in cheese with reference to bitter flavour. In: XVI Int Dairy Congr $B$ (sec IV), 353-361

Stadhouders J (1974) Dairy starter cultures. Milchwissenschaft 29, 329-337

Stadhouders J, Hup G (1975) Factors affecting bitter flavour in Gouda cheese. Neth Milk Dairy J 29, 335-353

Stanley DW (1981) Non-bitter protein hydrolysates. Can Inst Food Sci Technol J 14, 49-52

Stone WK, Naff DM (1967) Increases in soluble nitrogen and bitter flavor development in Cottage cheese. J Dairy Sci 50, 1497-1500

Sullivan JJ, Jago GR (1970) A model for bitter peptide formation and degradation in cultured dairy products. Aust J Dairy Technol 25, 111

Sullivan JJ, Jago GR (1972) The structure of bitter peptides and their formation from casein. Aust J Dairy Technol 27, 98-104

Sullivan JJ, Mou L, Rood JI, Jago GR (1973) The enzymic degradation of bitter peptides by starter streptococci. Aust J Dairy Technol $28,20-26$

Sullivan JJ, Schlipalius LE, Mou L, Jago GR (1974) Heat lability of starter cultures and its use in selecting potentially non-bitter strains. Aust J Dairy Technol 29, 71-74

Svendsen IB (1976) Chemical modifications of the subtilisins with special reference to the binding of large substrates. A review. Carlsberg Res Commun 41, 237-291 
Szejtii J (1981) Cyclodextrins in foods, cosmetics and toiletries. In: 1st int Symp on Cyclodextrins (Proc) Budapest, Hungary, 469-480

Tamura M, Mori N, Miyoshi T, Koyama S, Kohri $H$, Okai $H$ (1990) Practical debittering using model peptides and related compounds. $\mathrm{Ag}$ ric Biol Chem 54, 41-51

Tanford C (1962) Contribution of hydrophobic interactions to the stability of the globular conformation of proteins. J Am Chem Soc 84, 4240-4247

Tokita $F$ (1969a) Infrared spectroscopy investigation on the secondary structure of a bitter taste peptide. Milchwissenschaft 24, 142144

Tokita $F$ (1969b) Enzymatische und nichtenzymatische ausschaltung des bittergeschmacks bei enzymatischen eiweißhydrolysaten. $Z$ Lebensm Unters Forsch 138, 351-355

Umetsu H, Ichishima E (1988) Mechanism of digestion of bitter peptides from soybean protein by wheat carboxypeptidase. Nippon Shokuhin Kogyo Gakkaishi (J Jpn Soc Food Sci Technol) 35, 440-447

Umetsu H, Matsuoka H, Ichishima E (1983) Debittering mechanism of bitter peptides from milk casein by wheat carboxypeptidase. $J$ Agric Food Chem 31, 50-53

Vassal L, Gripon JC (1984) L'amertume des fromages à pãte molle de type Camembert: rôle de la présure et de Penicillium caseicolum, moyens de la contrôler. Lait 64, 397-417

Vegarud GE, Langsrud T (1989) The level of bitterness and solubility of hydrolysates produced by controlled proteolysis of caseins. $J$ Dairy Res 56, 375-379

Visser FMW (1977a) Contribution of enzymes from rennet, starter bacteria and milk to proteolysis and flavour development in Gouda cheese. 2. Development of bitterness and cheese flavour. Neth Milk Dairy $J 31,188$ 209

Visser FMW (1977b) Contribution of enzymes from rennet, starter bacteria and milk to proteolysis and flavour development in Gouda cheese. 3. Protein breakdown: analysis of the soluble nitrogen and amino acid nitrogen fractions. Neth Milk Dairy J 31, 210-239

Visser FMW (1977c) Contribution of enzymes from rennet, starter bacteria and milk to pro- teolysis and flavour development in Gouda cheese. 5. Some observations on bitter extracts from aseptically made cheeses. Neth Milk Dairy J 31, 265-276

Visser FMW, de Groot-Mostert AEA (1977) Contribution of enzymes from rennet, starter bacteria and milk to proteolysis and flavour development in Gouda cheese. 4. Protein breakdown: a gel electrophoretical study. Neth Milk Dairy J31, 247-264

Visser S (1981) Proteolytic enzymes and their action on milk proteins. A review. Neth Milk Dairy J 35, 65-88

Visser S, Slangen KJ (1977) On the specificity of chymosin (rennin) in its action on bovine $\beta$ casein. Neth Milk Dairy J 31, 16-30

Visser S, Slangen KJ, Hup G (1975) Some bitter peptides from rennet-treated casein. A method for their purification, utilizing chromatographic separation on silica gel. Neth Milk Dairy J 29, 319-334

Visser S, Hup G, Exterkate FA, Stadhouders J (1983a) Bitter flavour in cheese. 2. Model studies on the formation and degradation of bitter peptides by proteolytic enzymes from calt rennet, starter cells and starter cell fractions. Neth Milk Dairy J 37, 169-180

Visser S, Slangen KJ, Hup G, Stadhouders J (1983b) Bitter flavors in cheese. 3. Comparative gel-chromatographic analysis on hydrophobic peptide fractions from twelve Goudatype cheeses and identification of bitter peptides isolated from a cheese made with Streptococcus cremoris strain HP. Neth Milk Dairy J 37, 181-192

Visser S, Slangen KJ, Hup G, Exterkate FA, Stadhouders J (1983c) The bitter flavour defect in cheese; some chemical and microbiological aspects. Neth Milk Dairy J 37, 250251

Visser S, Slangen CJ, Exterkate FA, de Veer GJCM (1988) Action of a cell wall proteinase $\left(P_{1}\right)$ from Streptococcus cremoris HP on bovine $\beta$-casein. Appl Microbiol Biotechnol 29 . 61-66

Wieser H, Belitz HD (1975) Bitter peptides isolated from corn protein zein by hydrolysis with pepsin. Z Lebensm Unters Forsch 159, 329-336

Wieser H, Belitz HD (1976) Relations between structure and bitter taste of amino acids and 
peptides. II. Peptides and their derivatives. $Z$ Lebensm Unters Forsch 160, 383-392

Yamaguchi S (1991) Basic properties of umami and effects on humans. Physiol Behav 49, 833-841

Yamashita M, Arai S, Fujimaki M (1969) Applying proteolytic enzymes on soybean. Part IV. A ninhydrin-negative bitter peptide in peptic hydrolyzate of soybean protein. Agric Biol Chem 33, 321-330

Zvyagintsev VI, Buzov IP, Belov AN, Novgorodova NS (1972) Study of certain properties of bitter decomposition products of casein and investigation of the possibility of their hydrolysis. Prikl Bioklim Mikrobiol 8, 287-291 